(C) 2020, The Authors. Published by Elsevier Inc. and Fass Inc. on behalf of the American Dairy Science Association ${ }^{\circledR}$. This is an open access article under the CC BY-NC-ND license (http://creativecommons.org/licenses/by-nc-nd/4.0/).

\title{
Associations between lying behavior and activity and hypocalcemia in grazing dairy cows during the transition period
}

\author{
S. J. Hendriks, ${ }^{1 *} \odot$ J. M. Huzzey, ${ }^{2} \odot$ B. Kuhn-Sherlock, ${ }^{3} \odot$ S.-A. Turner, ${ }^{3} \dagger \odot$ K. R. Mueller, ${ }^{4} \odot$ C. V. C. Phyn, ${ }^{3} \odot$ \\ D. J. Donaghy, ${ }^{1}$ (1) and J. R. Roche ${ }^{3,5} \ddagger$ () \\ ${ }^{1}$ School of Agriculture and Environment, Massey University, Palmerston North 4442, New Zealand \\ ${ }^{2}$ Department of Animal Science, California Polytechnic State University, San Luis Obispo, 93407 \\ ${ }^{3}$ DairyNZ Ltd., Hamilton 3240, New Zealand \\ ${ }^{4}$ School of Veterinary Sciences, Massey University, Palmerston North 4442, New Zealand \\ ${ }^{5}$ School of Biological Sciences, University of Auckland, Private Bag 92019, Auckland 1142, New Zealand
}

\begin{abstract}
Hypocalcemia is a common metabolic disorder of transition dairy cows that is considered a gateway disease, increasing the risk of other health disorders and reducing cow performance. Clinical milk fever is associated with long periods of recumbency, and it is plausible that cows experiencing non-paretic hypocalcemia may spend more time lying; hence, lying behavior and activity measures may be useful in identifying at-risk cows. The objective of this study was to describe associations among blood calcium (Ca) status at calving and lying behavior and activity measures during the transition period in grazing dairy cows. Blood was sampled on the day of calving (d 0), and d 1, 2, 3, and 4 postcalving, and analyzed for total plasma Ca concentration. Twenty-four multiparous Holstein-Friesian and Holstein-Friesian $\times$ Jersey grazing dairy cows were classified, retrospectively, as clinically hypocalcemic (CLIN; blood Ca $\leq 1.4 \mathrm{mmol} / \mathrm{L}$ at 1 or more consecutive samplings within $48 \mathrm{~h}$ postcalving, but without parturient paresis). These cows were pair-matched (using milk production potential from their estimated breeding value for milk protein, mean body weight at wk -5 and -6 precalving, and, where possible, parity) with 24 cows classified as subclinically hypocalcemic (SUB; blood $\mathrm{Ca}>1.4$ and $<2.0 \mathrm{mmol} / \mathrm{L}$ at 2 consecutive samplings within $48 \mathrm{~h}$ postcalving), and 24 cows classified as normocalcemic (NORM; blood $\mathrm{Ca} \geq$ $2.0 \mathrm{mmol} / \mathrm{L}$ at 3 consecutive samplings within $72 \mathrm{~h}$ postcalving). Lying behavior and activity were monitored using triaxial accelerometers from -21 to $+35 \mathrm{~d}$
\end{abstract}

Received December 23, 2019.

Accepted June 11, 2020.

*Corresponding author: s.hendriks@massey.ac.nz

†Current address: Dairy Goat Co-operative, PO Box 1398, Hamilton 3240, New Zealand.

$\ddagger$ Current address: Ministry for Primary Industries, Wellington 6140, New Zealand. relative to calving. Data were summarized to calculate daily lying time $(\mathrm{h} / \mathrm{d})$, daily number of lying bouts (LB; no./d), mean LB duration (min/bout), and the number of steps taken (steps/d). On d 0, the CLIN group were less active and spent approximately $2.6 \mathrm{~h}$ longer lying than the SUB and NORM groups, particularly between 0200 and $1400 \mathrm{~h}$. On d 0, the NORM group had fewer LB $(16.3 / d)$ than the SUB and CLIN groups (18.2 and $19.2 / \mathrm{d}$, respectively). These differences in behavior were no longer detected $2 \mathrm{~d}$ postcalving, and no further differences were observed. The day before calving, the CLIN group spent $1.4 \mathrm{~h}$ longer lying down than did the SUB and NORM groups. Further, the relative change in steps from a precalving baseline period (d -14 to -7 ) until d 0 was positively, linearly associated with blood Ca concentration within $24 \mathrm{~h}$ postcalving. Future work should consider daily and temporal changes in behavior in individual cows to determine the potential for these measures to allow early detection of hypocalcemia.

Key words: activity, metabolic disease, pasture, lying time

\section{INTRODUCTION}

Hypocalcemia usually occurs when a dairy cow is unable to adapt to the increased physiological demand for calcium at the onset of lactation and maintain eucalcemia (Goff, 2008). Almost all cows experience some degree of hypocalcemia during the first days after calving, as it can take 1 to $2 \mathrm{~d}$ for macromineral adaptation to occur (Horst et al., 1994; Goff, 1999). Cows with hypocalcemia are generally identified within the first 12 to $24 \mathrm{~h}$ postcalving (Oetzel, 2004; Roche and Berry, 2006; Goff, 2008).

Clinical hypocalcemia is characterized as blood $\mathrm{Ca}$ concentrations $<1.4 \mathrm{mmol} / \mathrm{L}$ (Lindsay and Pethick, 1983; Martín-Tereso and Martens, 2014), and subclinical hypocalcemia is usually characterized as blood $\mathrm{Ca}$ $<2.0 \mathrm{mmol} / \mathrm{L}$ (Oetzel, 2004; Goff, 2008; Reinhardt et 
al., 2011). These thresholds do not correlate with the appearance of clinical symptoms that accompany the severe form of hypocalcemia known as parturient paresis or milk fever (Horst et al., 1997; Martín-Tereso and Martens, 2014). Cows are stoic animals (Fitzpatrick et al., 2002; Weary et al., 2009); therefore, we expect that cows experiencing subclinical or clinical hypocalcemia may display more subtle behavioral changes, making the conditions difficult to visually detect.

The prevalence of subclinical hypocalcemia is significant in both housed (range: 25 to 54\%; Reinhardt et al., 2011; Ribeiro et al., 2013) and grazing cows (range: 30 to 40\%; Roche, 2003; Roberts and McDougall, 2019), and is dependent on parity (Horst et al., 1997; Roche and Berry, 2006). Milk fever, itself, has been reported as a risk factor for other metabolic, infectious, and reproductive disorders (Goff, 2008; DeGaris and Lean, 2008; Martinez et al., 2012), and recent work in housed cows indicates that cows with subclinical hypocalcemia within 4 DIM are more likely to experience a disease event [e.g., displaced abomasum (Chapinal et al., 2011), metritis (Neves et al., 2018), and hyperketonemia] or herd removal (McArt and Neves, 2020). The high incidence of subclinical hypocalcemia and potential effects on health, due to the important role that calcium plays in immune function and smooth and skeletal muscle contractility (Goff, 2008; Murray et al., 2008), support a focus on developing new approaches to identify at-risk cows (Neves et al., 2017). Predicting hypocalcemia and ultimately improving diagnostic and treatment outcomes may be possible by monitoring cow behavior, but the behavioral changes associated with hypocalcemia must first be characterized (Weary et al., 2009; Proudfoot and Huzzey, 2017).

Long lying times and a reduction in activity (i.e., paresis) are common sickness behaviors and are clinical symptoms of milk fever (Hart, 1988). We therefore hypothesized that grazing cows with subclinical or clinical hypocalcemia spend more time lying down and have reduced activity compared with normocalcemic cows. The objective of the current study was to investigate whether cows classified, retrospectively, as subclinically and clinically hypocalcemic, but without clinical milk fever (i.e., parturient paresis), displayed behavioral differences pre- and postcalving compared with cows classified as normocalcemic.

\section{MATERIALS AND METHODS}

\section{Animal Management and Experimental Design}

The Ruakura Animal Ethics Committee (Hamilton, New Zealand) approved all animal manipulations in accordance with the New Zealand Animal Welfare Act (Ministry for Primary Industries, 1999). Data for the present study were selected from a data set of 143 spring-calving, pasture-grazing cows described by Roche et al. (2015, 2017), which included feeding $\times$ BCS treatments. A subset of 72 Holstein-Friesian and Holstein-Friesian $\times$ Jersey cows were selected from 2 separate parent experiments. The BCS (Roche et al., 2015) and feed (Roche et al., 2017) studies were undertaken across 2 separate seasons (2013 and 2014, respectively) and 2 locations (Scott Farm and Lye Farm; Hamilton, New Zealand, both $37^{\circ} 46^{\prime} \mathrm{S} 175^{\circ} 18^{\prime} \mathrm{E}$ ).

Experimental methods for parent experiments are explained in detail by Roche et al. (2015, 2017). Briefly, however, cows from Roche et al. (2015) were either BCS 4.0 or 5.0 at 1 mo before calving (10-point scale, where 1 is emaciated and 10 obese; Roche et al., 2004). Cows within each BCS were then allocated 1 of 3 levels of energy intake during the 3 wk preceding calving (75, 100 , or $125 \%$ of estimated ME requirements), but all cows were managed similarly postcalving (Roche et al., 2015). In a subsequent study (Roche et al., 2017), cows were at 1 of 2 BCS at dry-off (approximately 4.25 and 5.0 on a 10-point scale). Following dry-off, cows in both BCS categories were managed to achieve a BCS 5.0 at 1 mo before calving. Cows within each "far off" feeding level treatment were then allocated to 1 of 3 levels of energy intake during the $3 \mathrm{wk}$ preceding calving (65, 90, or $120 \%$ of estimated ME requirements; Roche et al., 2017). In both studies, all cows were managed similarly postcalving; cows were milked twice daily in a rotary parlor and spent approximately 40 to $90 \mathrm{~min} / \mathrm{d}$ standing waiting and walking to and from the milking parlor ( $\sim 1$ to $2.5 \mathrm{~km} / \mathrm{d}$ walked on tracks).

\section{Blood Sampling and Analyses}

Blood was sampled by coccygeal venipuncture weekly, from wk 4 pre- to wk 5 postcalving, and additionally on $\mathrm{d} 0$, and $\mathrm{d} 1,2,3$, and 4 postcalving in both studies. Blood was collected in evacuated blood tubes containing lithium heparin anticoagulant (Becton Dickinson Vacutainer Systems, Franklin Lakes, NJ). Heparinized samples were placed immediately into iced water and were centrifuged within 30 min of collection at 1,500 $\times g$ for $12 \mathrm{~min}$ at $4^{\circ} \mathrm{C}$. Following centrifugation, aspirated plasma was stored at $-20^{\circ} \mathrm{C}$ until assayed. Plasma samples were submitted to Gribbles Veterinary Pathology Ltd. (Hamilton, New Zealand) for analysis. Blood metabolites were assayed using colorimetric techniques at $37^{\circ} \mathrm{C}$ with a Hitachi Modular P800 analyzer (Roche Diagnostics, Indianapolis, IN). Roche reagent kits were used to measure plasma concentrations of 
BHB (mmol/L; reduction of $\mathrm{NAD}^{+}$to $\mathrm{NADH}$ during oxidation of D-3-hydroxybutyrate to acetoacetate), Ca (mmol/L; o-cresolphthalein complexone method), and magnesium (mmol/L; xylidyl blue reaction). Plasma nonesterified fatty acids (NEFA, mmol/L) concentrations were measured using Wako Chemicals (Osaka, Japan) kit NEFA HR2, measuring oxidative condensation of 3-methyl-N-ethyl-N- $\beta$ hydroxyethyl aniline with 4 -aminoantipyrine. The inter- and intra-assay coefficients of variation for all assays were $<5.5 \%$ and $\leq 15 \%$, respectively, as reported in Roche et al. $(2015,2017)$.

\section{Categorization of Ca Status}

Blood Ca and behavior data were available from 143 cows for analysis; a subset of 72 cows was established based on blood Ca status for statistical analysis. A cow was classified as being clinically hypocalcemic (CLIN) when blood $\mathrm{Ca}$ concentration was $\leq 1.4 \mathrm{mmol} / \mathrm{L}$ at 1 or more consecutive samplings within $48 \mathrm{~h}$ postcalving, but parturient paresis was not observed (Lindsay and Pethick, 1983). A cow was classified as subclinically hypocalcemic (SUB) when blood Ca concentrations were $>1.4$ and $<2.0 \mathrm{mmol} / \mathrm{L}$ at 2 consecutive samplings within $48 \mathrm{~h}$ postcalving (Goff, 2008). Of 143 cows, 37 were not allocated to a group due to a lack of consecutive samples meeting the defined classification criteria for the $3 \mathrm{Ca}$ groups. Of the remaining 106 cows, 36 were identified as CLIN within $48 \mathrm{~h}$ postcalving, 26 were identified as SUB, and 44 were identified as normocalcemic (NORM; serum Ca concentration $\geq 2.0$ $\mathrm{mmol} / \mathrm{L}$ at 3 consecutive samplings within $72 \mathrm{~h}$ postcalving). The 36 CLIN cows were each pair-matched with a SUB cow and NORM cow using EBV for milk protein, mean BW precalving (wk -5 and -6 ), and, where possible, parity. Milk protein EBV (data kindly provided by Livestock Improvement Corporation Ltd., Hamilton, New Zealand) was used as a proxy measure for milk protein production potential to pair-match cows, as suitable milk component and volume records were unavailable from previous lactations. Most $\mathrm{Ca}$ in milk is contained in the casein micelle, and therefore, milk protein production is a good proxy for Ca secretion in milk (Gambra et al., 2013). Parity was grouped as follows: parity 2 and $3(\mathrm{n}=44)$, and parity 4 to 7 (n $=28)$. All cows included in the study were multiparous (i.e., approaching their second or greater lactation at the time of calving). A lesser representation of greaterparity cows was due to fewer animals fitting the criteria for the SUB or NORM groups. After matching cows based on the outlined criteria, 24 cows were available for each blood Ca category (24 CLIN cows balanced with 24 NORM cows and 24 SUB cows), and these animals were used for all further analyses.

\section{Milk, BCS, BW, and Breed}

Cows were milked twice daily, and individual milk yields were measured at each milking from 1 to 49 DIM using either the Westfalia Surge Metatron Milk Meter (GEA Farm Technologies, Cambridge, New Zealand) or the DeLaval Milk Meter (DeLaval Ltd., Hamilton, New Zealand) for BCS and feed studies, respectively. Milk was sampled once weekly on consecutive afternoon and morning milkings, and a composite sample was analyzed for milk composition by infrared analysis (FT120, Foss Electric, Hillerød, Denmark). Energycorrected milk yield was calculated as follows (Nielsen et al., 2009):

$$
\begin{gathered}
\mathrm{kg} \text { of } \mathrm{ECM}=[\mathrm{kg} \text { of milk } \times(383 \times \text { fat } \%+242 \\
\times \operatorname{protein} \%+780.8)] / 3,140 .
\end{gathered}
$$

Body weight was recorded and BCS determined weekly following the morning milking, or at approximately $0800 \mathrm{~h}$ during the nonlactating period. All BCS assessors were trained and recalibrated at the start of the experiment following the procedures set out in Macdonald and Roche (2011). Animal evaluation data for cow breed, breeding worth, and production worth (PW) were kindly provided by Livestock Improvement Corporation Ltd. Breeding worth and PW are estimated economic values of a combination of 8 traits (milk fat, protein, milk volume, BW, fertility, SCC, BCS, and residual survival) that are indicators of robustness and production efficiency (DairyNZ, 2018; Johnson et al., 2018). Breeding values are the genetic potential of an animal for the trait of interest, and the weighted combination of all $8 \mathrm{EBV}$ traits contribute to the breeding worth (DairyNZ, 2018). Milk protein EBV was used instead of milk production records due to the experimental cows being involved in studies during previous seasons that may have affected their historical records.

\section{Behavioral Data and Editing}

A full description of the behavioral data collection and editing methods is given in Hendriks et al. (2019). Behavioral data were available for the period $-21 \mathrm{~d}$ precalving to $+35 \mathrm{~d}$ postcalving. In brief, each cow was fitted with a triaxial accelerometer (IceTag or IceQube; IceRobotics Ltd., Edinburgh, Scotland) on the lateral side of a hind leg, and behavioral data were recorded. Data were downloaded using the IceManager 2010 software (IceRobotics Ltd.) from the on-board memory of the device. Two summary files were generated for each individual cow; one file consisted of lying time (s) and number of steps recorded at 1- and 15-min 
sampling intervals, for the IceTag and IceQube, respectively, and the other file contained lying bouts (LB) recorded by day, time stamp (hh:mm:ss), and duration (s; Mattachini et al., 2013; Kok et al., 2015). These summary files were used to calculate daily lying time (h/d), LB (no./d), mean LB duration (min/bout), and number of steps (steps/d) for each cow. Hourly lying time $(\mathrm{min} / \mathrm{h})$ and number of steps (steps/h) were also calculated from these summary files. An LB is defined as the period between the activity monitor changing from vertical to horizontal and back to vertical. Data excluded from the analysis were data recorded on the day that the accelerometers were removed or fitted to the cows and incorrect accelerometer recordings due to technical errors. In the current study, based on previously determined thresholds for IceRobotics sensors, LB $<33$ s (Kok et al., 2015) and $\leq 2$ min (Mattachini et al., 2013) were discarded from the raw data recorded by the IceQube and IceTag devices, respectively.

From the output data sets, the sampling dates for each individual cow were assigned an experimental day relative to d 0 (recorded calving date). After visual inspection of the data on a per-cow basis, it was evident that a peak in LB frequency was occurring on $\mathrm{d}-1$ and not on d 0 for some cows. As is common in grazing dairy systems, farm staff collected newborn calves and their dams once daily (Lawrence et al., 2017). Consequently, a discrepancy of up to $24 \mathrm{~h}$ may occur for the recording of the date of calving. Where we have recorded data that supersedes the day of "calf collection," we reassigned the calving day using activity data. Previous studies report an average of $14 \mathrm{LB} / \mathrm{d}$ on the day of calving (Huzzey et al., 2005; Borchers et al., 2017; Rice et al., 2017). In our study, we assumed that where LB were $<14$ on $\mathrm{d} 0$, but were $\geq 14 \mathrm{LB}$ on $\mathrm{d}-1$, was likely associated with a calving event and therefore adjusted the calving date to reflect this. Otherwise, it was assumed that recorded calving date was correct. The methodology used to adjust for the discrepancy in assignment of calving day has not been validated, and this is a limitation of our study.

\section{Weather Data}

Daily rainfall ( $\mathrm{mm} ; 24$-h period) and daily air temperature $\left({ }^{\circ} \mathrm{C}\right.$; recorded at $0900 \mathrm{~h}$ ) data were retrieved from the National Climate Database (NIWA, 2018) for the duration of the 2 experiments. Data were retrieved from station agent number $26,117\left(37.8^{\circ} \mathrm{S}, 175.3^{\circ} \mathrm{E}\right)$ for the BCS and feed studies (NIWA, 2018). The distance from the climate station to the study site for the BCS and feed studies is approximately $3 \mathrm{~km}$.

\section{Statistical Analyses}

Statistical analyses were performed using SAS 9.4 (SAS Institute Inc., Cary, NC). Results are presented as least squares means (LSM) \pm standard error of the mean in the text and tables, and mean standard error of the difference in figures. Where we have presented LSM for the 3 Ca groups, we have presented group mean effects. The covariance structures selected were compound symmetry or autoregressive based on the lowest Akaike's information criterion. All repeated measures ANOVA models were pairwise comparison-adjusted using Tukey-Kramer. Residuals for cow performance, behavioral, and blood measures were checked to ensure that assumptions of normality and homogeneity of variance were met. Study and treatment from the parent experiments were concatenated to create a categorical variable, study group. All data were adjusted where appropriate, according to the reassigned calving day, and these transformed data sets were the basis of subsequent analyses.

Study group (categorical), parity (categorical; $2-3$ or $4+$ ), and difference in days between calving date and the first day in June (calvingseasonday) were included in all models described to adjust for different treatments within the 2 studies, parity differences, and different calving dates.

Behavioral Variables. Lying behavior and activity data pre- and postcalving were first analyzed to determine mean differences in the group means between the Ca groups for both daily and hourly data. Following this analysis, we further investigated whether the change in behavior from a precalving baseline period to $\mathrm{d}-1$ or d 0 was associated with blood Ca concentrations. Change in daily and hourly lying time and number of steps taken within cow were included in these subsequent models. Understanding both daily and temporal changes in behavior that precede changes in blood $\mathrm{Ca}$ concentrations may provide important information for future work in identifying cows at risk of developing hypocalcemia. Due to differences in lying time and steps taken between the $3 \mathrm{Ca}$ groups between 0600 and $1800 \mathrm{~h}$, we further investigated these associations. Specifically, to reflect changes in behavior occurring during the daytime, the hourly data were further summarized to include only data recorded between 0600 and $1800 \mathrm{~h}$, referred to herein as hourly daytime lying time and steps taken. The linear and nonlinear associations between change in daily and hourly daytime lying time and number of steps taken precalving (dependent variables) and blood $\mathrm{Ca}$ concentrations postcalving (independent variable) were investigated. The separate analyses are described in detail as follows. 
Differences in Lying Time and Activity Associated with Ca Status. Behavior data were summarized for 15 periods: wk -3 and -2 precalving, $\mathrm{d}-7$ to -4 precalving, daily precalving $(\mathrm{d}-3$ to -1$)$, d 0 , daily postcalving (d 1 to 3 ), d 4 to 7 postcalving, and wk 2, 3,4 , and 5 postcalving. Differences in daily lying time, daily number of LB, mean LB duration, and number of steps taken between the $3 \mathrm{Ca}$ groups were analyzed using a repeated measures ANOVA (PROC MIXED) with cow as a random effect, period as a repeated measure, and the fixed effect of Ca status, period, and Ca status $\times$ period interactions. Behavior analyses included fixed effect of daily rainfall (continuous, $\mathrm{mm} / \mathrm{d}$ ) and mean air temperature at $0900 \mathrm{~h}$ (continuous) and interactive effect of rainfall and air temperature as potential explanatory variables.

Differences in Hourly Behavioral Variables Within Day Associated with Ca Status. Upon examination of the blood Ca profile, we identified d -2 to $\mathrm{d}+2$ relative to calving as the critical time for risk of hypocalcemia, making this period suitable for evaluating within-day associations among $\mathrm{Ca}$ status and behavior and activity variables. We were unable to adjust the data according to the exact time of calving; therefore, within each day from $\mathrm{d}-2$ precalving to $\mathrm{d} 2$ postcalving, 24-h behavior data were summarized into 4-h time intervals (i.e., 0200 to 0559 h, 0600 to 0959 h, 1000 to 1359 h, 1400 to 1759 h, 1800 to 2159 h, 2200 to $0159 \mathrm{~h}$ ). Behavior data were analyzed separately within day for $\mathrm{d}-2$ to $\mathrm{d}+2$ relative to calving using a repeated measures ANOVA (PROC MIXED) to investigate differences in lying time and number of steps taken over a 24 -h period due to Ca status. Time interval was included as fixed and cow as random effects, and hour as a repeated measure. On $\mathrm{d}-2$ precalving and d 2 postcalving, lying time or number of steps taken was not different between Ca status groups within the time periods investigated; therefore, the data are not presented.

Linear and Nonlinear Associations of Change in Daily and Hourly Daytime Lying Behavior and Activity Precalving with Blood Ca Postcalving. Linear and nonlinear associations of change in daily lying time, daily steps taken, hourly daytime lying time, and hourly daytime steps taken with blood Ca concentrations $24 \mathrm{~h}$ postcalving were investigated.

Blood Ca data were summarized for $\mathrm{d} 0, \mathrm{~d} 1$, and $\mathrm{d}$ 2 postcalving, and lying time and activity data were summarized for 4 periods immediately before calving and surrounding the calving event using PROC MEAN on a per-cow basis for all 72 cows. A detailed description of the periods investigated and descriptive data for summarized blood Ca concentrations and behavior and activity data are presented in Supplemental Tables
S1 and S2, respectively (https://doi.org/10.3168/jds .2019-18111). All summarized behavior and blood Ca variables formed the dependent and independent variables, respectively. Pearson correlations were generated for summarized behavior variables and blood Ca using PROC CORR, and the correlation matrix is presented in Supplemental Table S3 (https://doi.org/10.3168/jds .2019-18111). The strongest associations were selected for further analysis.

The independent variable selected was the blood $\mathrm{Ca}$ concentration within $24 \mathrm{~h}$ postcalving. The dependent variables selected were change in daily and hourly daytime lying time and steps taken, calculated as the difference between the behavior on $\mathrm{d} 0$ and mean precalving baseline period ( $\mathrm{d}-14$ to -7$)$. Blood Ca concentration was modeled as a continuous measure and behavior variables as continuous effects in 4 separate analyses (2 daily and 2 hourly daytime models). Slopes of the estimated change in each behavior (dependent variable) were investigated using multiple regression analyses (PROC GLM), with blood Ca concentration within $24 \mathrm{~h}$ postcalving as the independent variable. Models included categorical effects of study group, breed, and parity, and continuous effects of calvingseasonday, breeding worth, PW, milk protein EBV, BW wk -5 to -6 precalving, BCS wk -5 to -6 precalving, and rainfall and air temperature, and their interactions as potential explanatory variables. Variables were checked for multicollinearity but were not highly correlated (variance inflation factors $\leq 10$ ). Nonsignificant variables were eliminated from the model one at a time where $P>0.10$, with the exception of study group and calvingseasonday, which were forced in the model even if not significant, to adjust for different treatments within the 2 studies and different planned start of calving dates. The final models for all variables investigated included the effect of study group, calvingseasonday, and parity. Both linear and quadratic associations were assessed for the behavior variables. The models that included behavioral variables without adjusting for other factors are presented in Supplemental Tables S4 and S5 (https://doi.org/10.3168/jds.2019-18111).

Milk, $B C S$, and $B W$. Weighted means for weekly milk yield were calculated using daily yields on a per-cow basis for wh 1 to 7 postcalving, using PROC MEAN. Weighted means for milk yield were used to calculate weekly milk component yields and ECM yield for wk 2 to 6 postcalving. Due to inconsistent records for milk composition data during wk 1 postcalving (colostrum period), these data were excluded from ECM yield analysis. To investigate the associations between milk and ECM, CP and fat yield, milk protein and fat composition, and $\mathrm{Ca}$ status, a repeated measures ANOVA was performed using PROC MIXED with cow 
as a random effect, week as a repeated measure, and the fixed effects of Ca status, week, and Ca status $\times$ week interactions. Breeding worth and PW as proxies for milk production potential were included in the model as covariates.

To investigate the associations between BCS and BW, and Ca status for 6 wk pre- and postcalving, a repeated measures ANOVA was performed using PROC MIXED, with cow as a random effect and fixed effects of Ca status, week, and Ca status $\times$ week interactions.

Blood Metabolite and Mineral Markers. Blood data for minerals ( $\mathrm{Ca}$ and $\mathrm{Mg}$ ) were summarized into 6 periods ( $\mathrm{d}-14$ to -1 precalving, $\mathrm{d} 0, \mathrm{~d} 1$ postcalving, d 2 postcalving, d 3 to 7 postcalving, and d 8 to 14 postcalving). Blood data for energy metabolites (BHB and NEFA) were summarized into 6 periods [d -14 to -1 precalving, d 0 to 2 postcalving, d 3 to 7 postcalving, and weekly postcalving (wk 2 to 4 )].

To investigate the associations between minerals and energy metabolites, and $\mathrm{Ca}$ status and period, a repeated measures ANOVA was performed using PROC MIXED with cow as a random effect, period as a repeated measure, and fixed effects of Ca status, period, and $\mathrm{Ca}$ status $\times$ period interactions. Variables were checked for skewness and normality. Blood BHB were log-transformed for analyses, and untransformed LSM, standard error of the mean, and standard error of the difference are presented.

\section{RESULTS AND DISCUSSION}

\section{Differences in Blood Ca and Mg Between Groups}

The mean and standard deviation for milk protein $\mathrm{EBV}$, wk -5 to -6 precalving BCS and BW, and number of cows by parity, breed, and study are presented in Table 1. Descriptive data presented for the 3 blood Ca groups indicate that our classification process was successful in categorizing groups with balanced phenotypes. As intended, mean blood Ca concentrations differed $(P<0.001)$ between the 3 blood Ca status groups. The profiles presented in Figure 1a indicate that our classification process was successful in categorizing groups with divergent plasma Ca concentrations at calving. A Ca status $\times$ period interaction was found $(P<0.001)$; on $\mathrm{d} 0$ and $\mathrm{d} 1$ postcalving, the CLIN group had a lower $(P<0.001)$ blood Ca concentration $(1.47 \pm 0.05 \mathrm{mmol} / \mathrm{L})$ than the SUB group, which had, in turn, a lower blood Ca concentration $(1.75 \pm 0.04$ $\mathrm{mmol} / \mathrm{L})$ than the NORM group $(2.16 \pm 0.05 \mathrm{mmol} / \mathrm{L}$; $P<0.001)$. Mean blood Mg concentration also tended to differ between Ca status groups during the period d -14 precalving to d 14 postcalving $(0.74 \pm 0.02,0.71$ \pm 0.02 , and $0.78 \pm 0.02 \mathrm{mmol} / \mathrm{L}$ for the NORM, SUB, and CLIN groups, respectively; $P=0.09$ ). However, no Ca status $\times$ period interaction occurred for blood $\mathrm{Mg}$ $(P=0.64$; Figure $1 \mathrm{~b})$.

Table 1. Mean \pm SD of milk protein EBV, wk -5 to -6 precalving BW and BCS, and number of cows (n) by parity, breed, and study for the 3 calcium groups (NORM, SUB, and CLIN) ${ }^{1}$

\begin{tabular}{|c|c|c|c|}
\hline Item & NORM & SUB & CLIN \\
\hline \multicolumn{4}{|l|}{ Mean \pm SD } \\
\hline Milk protein $\mathrm{EBV}^{2}$ & $17.7 \pm 6.41$ & $17.6 \pm 6.78$ & $16.4 \pm 6.93$ \\
\hline Wk -5 to -6 precalving & & & \\
\hline $\mathrm{BW}, \mathrm{kg}$ & $551.8 \pm 61.9$ & $557.0 \pm 45.3$ & $559.8 \pm 60.8$ \\
\hline $\mathrm{BCS}^{3}$ & $4.94 \pm 0.44$ & $4.93 \pm 0.41$ & $4.71 \pm 0.54$ \\
\hline \multicolumn{4}{|l|}{ n (cows) } \\
\hline Parity $2-3^{4}$ & 19 & 10 & 15 \\
\hline Parity $4+{ }^{4}$ & 5 & 14 & 9 \\
\hline Breed $(\mathrm{HF})^{5}$ & 17 & 13 & 20 \\
\hline Breed $(\mathrm{HF} \times \mathrm{J})^{5}$ & 7 & 11 & 4 \\
\hline BCS study $^{6}$ & 11 & 10 & 15 \\
\hline Feed study ${ }^{6}$ & 13 & 14 & 9 \\
\hline
\end{tabular}

${ }^{1}$ Cows $(\mathrm{n}=24$ per group) were classified as having clinical hypocalcemia (CLIN; blood $\mathrm{Ca}<1.4 \mathrm{mmol} / \mathrm{L}$ within $48 \mathrm{~h}$ postcalving but without parturient paresis), subclinical hypocalcemia (SUB; blood Ca $>1.4$ and $<2.0 \mathrm{mmol} / \mathrm{L}$ within $48 \mathrm{~h}$ postcalving), or normocalcemia (NORM; blood $\mathrm{Ca} \geq 2.0 \mathrm{mmol} / \mathrm{L}$ within $72 \mathrm{~h}$ postcalving).

${ }^{2}$ DairyNZ, 2018; Johnson et al., 2018.

${ }^{3} \mathrm{BCS}$ on a 10-point scale, where 1 is emaciated and 10 is obese (Roche et al., 2004).

${ }^{4}$ Parity $2-3=$ cows approaching their second or third parity at the time of calving; parity $4+=$ cows approaching their fourth, fifth, sixth, or seventh parity at the time of calving.

${ }^{5} \mathrm{HF}=$ Holstein-Friesian; HF $\times \mathrm{J}=\mathrm{HF} \times$ Jersey.

${ }^{6}$ Cows were selected from the BCS study described by Roche et al. (2015) or the feed study described by Roche et al. (2017). 


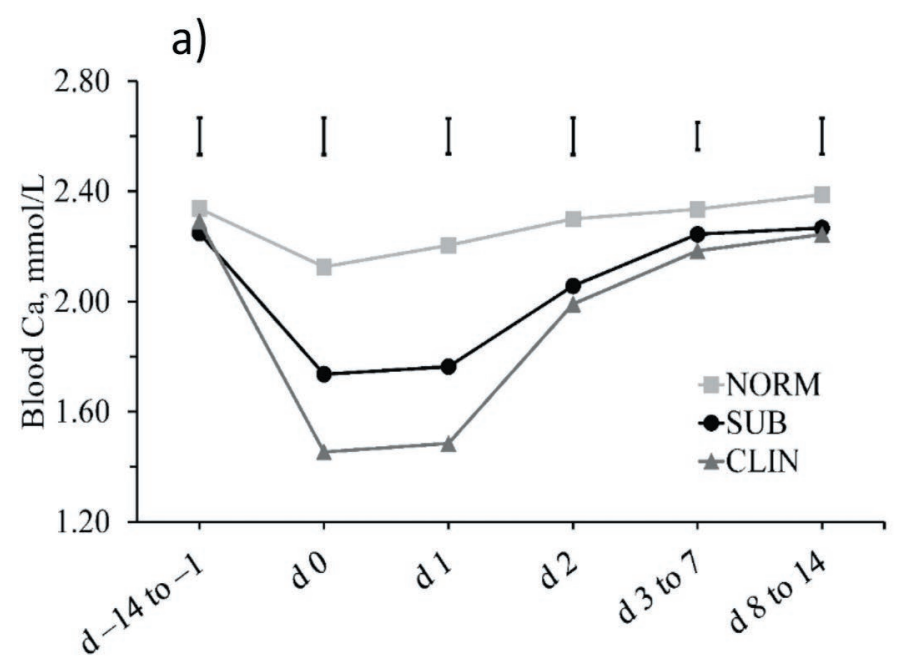

b)

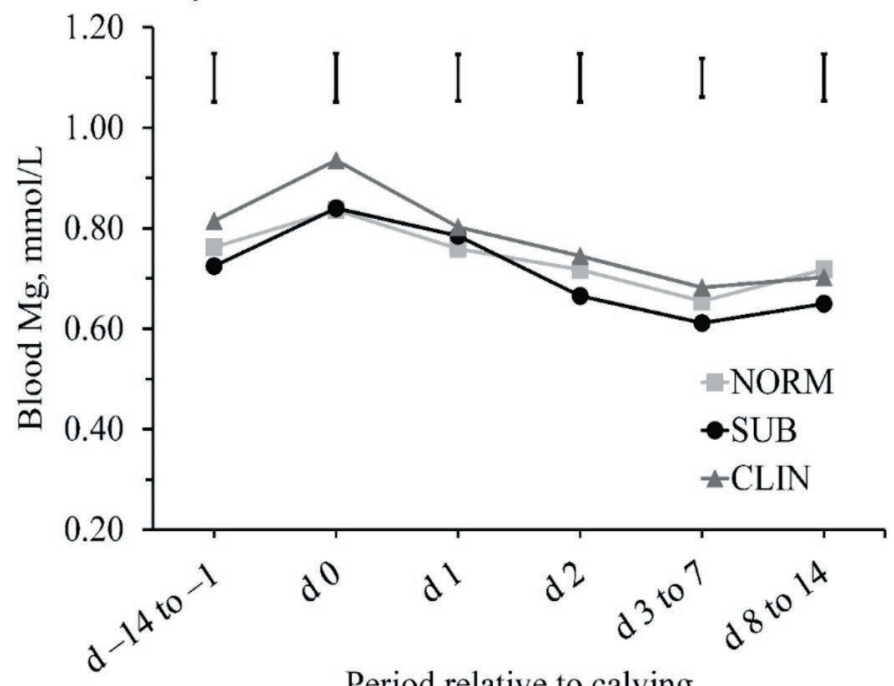

Figure 1. Blood $\mathrm{Ca}(\mathrm{a})$ and $\mathrm{Mg}(\mathrm{b})$ concentrations (mmol/L) during $\mathrm{d}-14$ to -1 precalving, the day of calving (d 0), d 1 postcalving, d 2 postcalving, d 3 to 7 postcalving, and d 8 to 14 postcalving for the 3 Ca groups. CLIN = clinical hypocalcemia (blood $\mathrm{Ca} \leq 1.4 \mathrm{mmol} / \mathrm{L}$ within $48 \mathrm{~h}$ postcalving); SUB = subclinical hypocalcemia (blood $\mathrm{Ca}$ $>1.4$ and $<2.0 \mathrm{mmol} / \mathrm{L}$ within $48 \mathrm{~h}$ postcalving); NORM = normocalcemia (blood $\mathrm{Ca} \geq 2.0 \mathrm{mmol} / \mathrm{L}$ within $72 \mathrm{~h}$ postcalving). Error bars represent $2 \times$ mean $\mathrm{SE}$ of the difference.

\section{Differences in Lying Time and Activity Associated with Blood Ca Status}

Quantitative measures of lying behavior and activity may allow early identification of clinical hypocalcemia in grazing dairy cows in time to provide preventative treatment and halt the progression to clinical milk fever, if hypocalcemia is preceded by changes in behavior that occur before calving. To our knowledge, this is the first study to investigate associations between blood $\mathrm{Ca}$ status and both pre- and postcalving lying behavior and activity in transition cows grazing pasture.

Daily lying time, daily LB, mean LB duration, and number of steps taken per day over the period -21 to $+35 \mathrm{~d}$ relative to calving are presented in Figures $2 \mathrm{a}, \mathrm{b}, \mathrm{c}$, and $\mathrm{d}$, respectively. Overall, no association was detected between Ca status and lying behavior variables and activity (Table 2); however, we found $\mathrm{Ca}$ status $\times$ period interactions for daily lying time $(P<$ $0.001)$, daily LB $(P<0.05)$, and number of steps taken $(P<0.001)$, and a trend $(P=0.09)$ for a Ca status $\times$ period interaction for LB duration. Herein, we consider 2 distinct types of behavior, referred to as "sickness behaviors" and "early indicators of disease." Sickness behaviors are well established as an evolutionary mechanism to support the body's response to combat disease (Hart, 1988), and are typically observed when the animal displays signs of clinical illness, involving highly coordinated physiological responses (Dantzer and Kelley, 2007). An expanding body of literature has been able to demonstrate that behavioral changes can occur well before disease diagnosis; these have been described as early indicators of disease (Proudfoot and Huzzey, 2017). Sickness behaviors are, therefore, deemed to be behaviors occurring from the day of calving onward, whereas behaviors observed before parturition will be referred to as early indicators of disease.

\section{Lying Time and Activity as Sickness Behaviors}

On the day of calving, cows in the CLIN group were less active $(3,118 \pm 274$ steps $/ \mathrm{d} ; P<0.05)$ and spent $\sim 2.6 \mathrm{~h}$ longer lying $(9.4 \pm 0.47 \mathrm{~h} / \mathrm{d} ; P<0.001)$ than cows in the SUB and NORM groups, which were not different from each other $(3,853 \pm 266$ vs. $4,448 \pm 285$ steps/d and $6.8 \pm 0.46$ vs. $6.8 \pm 0.49 \mathrm{~h} / \mathrm{d}$, respectively; Figure $2 \mathrm{a}$ and $\mathrm{d}$ ). The longer total daily lying time on $\mathrm{d}$ 0 in the CLIN group was predominantly driven by this group's greater number of LB (Figure 2b), as the mean LB duration did not differ between groups (Figure 2c). Cows in the CLIN group remained less active the day after calving than cows in the NORM group $(3,652 \pm$ 274 vs. $4,436 \pm 285$ steps $/$ d; $P<0.05$ ); however, both groups were not different from the SUB group $(3,982$ \pm 266 steps $/$ d).

Evidence indicates that sick cows generally spend more time lying (Kaufman et al., 2016; Barragan et al., 2018). In our study, few differences were recorded between the SUB and NORM groups; however, the differences we recorded in the CLIN group are consistent with the findings of Jawor et al. (2012), who reported that housed cows experiencing subclinical hypocalcemia (blood $\mathrm{Ca} \leq 1.8 \mathrm{mmol} / \mathrm{L}$ within $24 \mathrm{~h}$ of calving) spent more time lying (by $2.7 \mathrm{~h}$ on the day after calving) 
compared with normocalcemic cows (blood $\mathrm{Ca}>1.8$ $\mathrm{mmol} / \mathrm{L}$ within $24 \mathrm{~h}$ of calving). Sepúlveda-Varas et al. (2014) defined changes in lying behavior postcalving in grazing dairy cows; however, subclinical hypocalcemia was defined as blood $\mathrm{Ca} \leq 2.0 \mathrm{mmol} / \mathrm{L}$ between 3 and 22 $\mathrm{d}$ postcalving, thereby potentially failing to detect most hypocalcemic cows. In addition, cows were grouped according to the presence of 1 or more health events (i.e., retained placenta, metritis, mastitis, hypocalcemia, and subclinical ketosis), making it difficult to confidently understand differences in behavior specifically due to hypocalcemia. Our observed increase in lying time in the CLIN group may reflect an energy-conserving behavior associated with hypocalcemia (Johnson, 2002; Jawor et al., 2012) but is more likely a result of com- promised movement, due to the importance of $\mathrm{Ca}$ for skeletal muscle contraction (Murray et al., 2008; Jawor et al., 2012).

Few studies have investigated the association between blood Ca concentration and activity, and measurements are often different. Nevertheless, we find a consistent theme that activity declines in cows experiencing hypocalcemia, although the extent of the decline depends on the extent of the hypocalcemia. For example, Liboreiro et al. (2015) reported no associations between steps taken pre- and postcalving, possibly due to the relatively high blood Ca threshold used to define hypocalcemia (blood $\mathrm{Ca}<2.14 \mathrm{mmol} / \mathrm{L}$ within $72 \mathrm{~h}$ postcalving). Other studies, however, have reported reduced activity, such as self-grooming (Fogsgaard et al., 2012), and

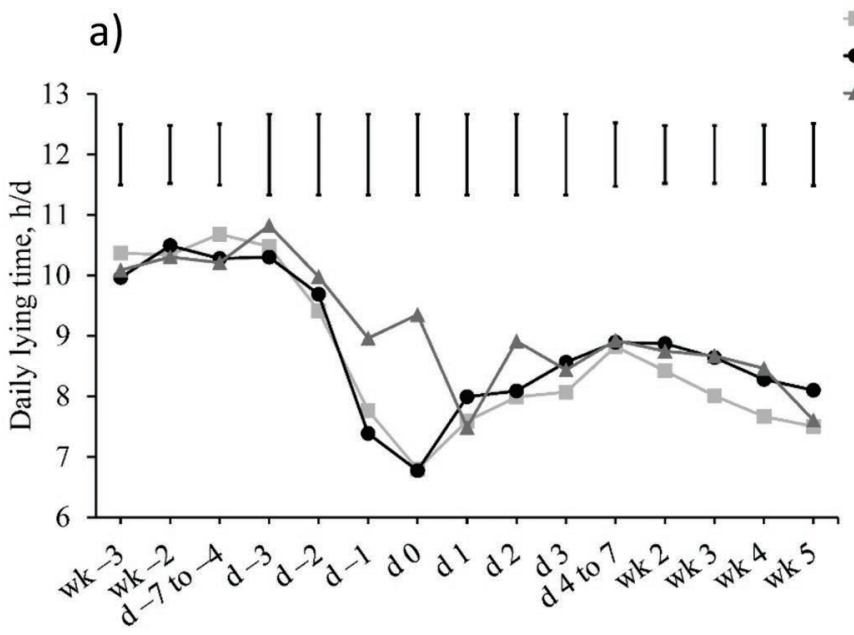

b)

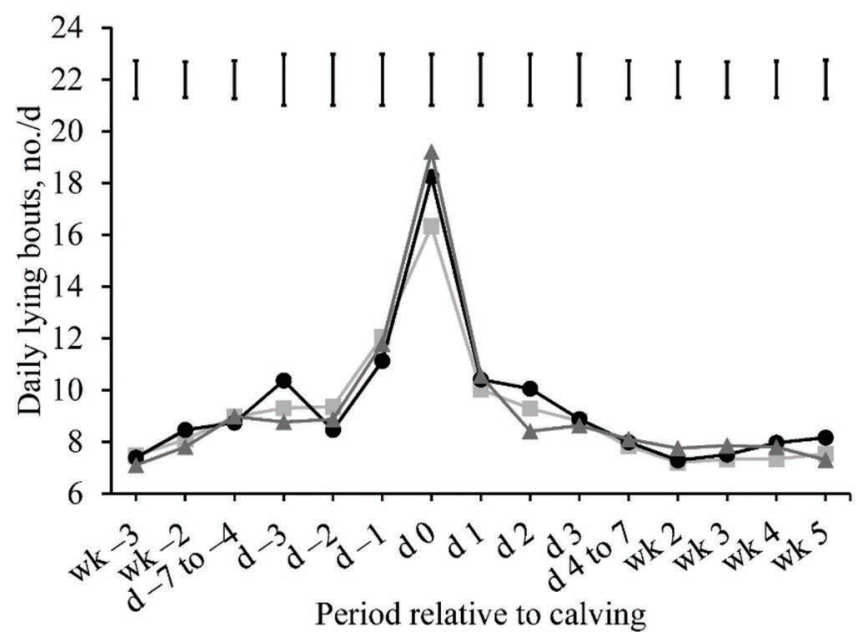

c)

NORM

-SUB

$₫ \mathrm{CLIN}$

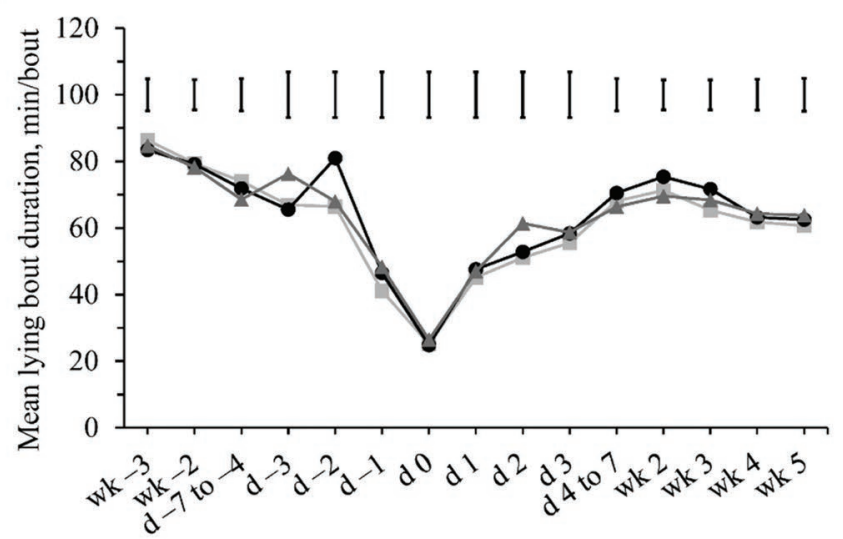

d)

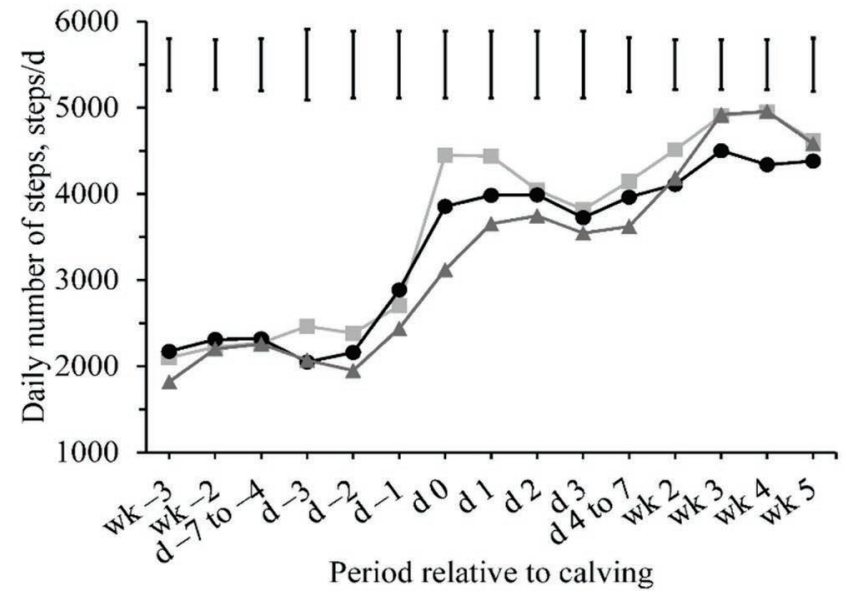

Figure 2. Daily lying time (a, h/d), lying bouts (b, no./d), mean lying bout duration (c, min/bout), and number of steps (d, steps/d) during the period -21 to $+35 \mathrm{~d}$ relative to the day of calving (d 0) in the $3 \mathrm{Ca}$ groups. CLIN $=$ clinical hypocalcemia (blood Ca $<1.4 \mathrm{mmol} / \mathrm{L}$ within $48 \mathrm{~h}$ postcalving); $\mathrm{SUB}=$ subclinical hypocalcemia (blood $\mathrm{Ca}>1.4$ and $<2.0 \mathrm{mmol} / \mathrm{L}$ within $48 \mathrm{~h}$ postcalving) $\mathrm{NORM}=\mathrm{normocalcemia}$ (blood $\mathrm{Ca} \geq 2.0 \mathrm{mmol} / \mathrm{L}$ within $72 \mathrm{~h}$ postcalving). Error bars represent $2 \times$ mean $\mathrm{SE}$ of the difference. 
Table 2. Mean lying behavior, activity, and cow performance measures for the 3 calcium groups (NORM, SUB, and CLIN $)^{1}$

\begin{tabular}{lcccc}
\hline Variable & NORM & SUB & CLIN & $P$-value \\
\hline Lying time, ${ }^{2} \mathrm{~h} / \mathrm{d}$ & 8.66 & 8.82 & 9.13 & 0.59 \\
Lying bouts (LB), ${ }^{2}$ no./d & 9.13 & 9.40 & 9.26 & 0.91 \\
LB duration, ${ }^{2} \mathrm{~min} / \mathrm{bout}$ & 61.2 & 63.6 & 63.3 & 0.82 \\
Steps taken, ${ }^{2}$ steps/d & 3,601 & 3,381 & 3,270 & 0.50 \\
Milk yield, ${ }^{3} \mathrm{~kg} / \mathrm{d}$ & 26.4 & 26.8 & 26.6 & 0.90 \\
ECM yield, ${ }^{4} \mathrm{~kg} / \mathrm{d}$ & 28.4 & 28.5 & 28.7 & 0.93 \\
CP yield, ${ }^{4} \mathrm{~kg} / \mathrm{d}$ & 0.93 & 0.93 & 0.94 & 0.93 \\
Fat yield, ${ }^{\mathrm{kg}} / \mathrm{d}$ & 1.15 & 1.19 & 1.21 & 0.36 \\
Milk protein, $\%$ & 3.47 & 3.42 & 3.46 & 0.61 \\
Milk fat, ${ }^{4} \%$ & 4.45 & 4.41 & 4.46 & 0.91 \\
BW, ${ }^{5} \mathrm{~kg}$ & 523 & 541 & 542 & 0.51 \\
BCS, ${ }^{5,6}$ units & 4.59 & 4.63 & 4.64 & 0.78 \\
\hline
\end{tabular}

$\overline{\mathrm{a}, \mathrm{b}}$ Means with different superscripts are significantly different at the $5 \%$ confidence level.

${ }^{1}$ Cows ( $\mathrm{n}=24$ per group) were classified as having clinical hypocalcemia (CLIN; blood Ca $\leq 1.4 \mathrm{mmol} / \mathrm{L}$ within $48 \mathrm{~h}$ postcalving but without parturient paresis), subclinical hypocalcemia ( $\mathrm{SUB}$; blood Ca $>1.4$ and $<2.0 \mathrm{mmol} / \mathrm{L}$ within $48 \mathrm{~h}$ postcalving), or normocalcemia (NORM; blood Ca $\geq 2.0 \mathrm{mmol} / \mathrm{L} \mathrm{within} 72 \mathrm{~h}$ postcalving).

${ }^{2}$ Behavior summarized for the period -21 to +35 d relative to calving.

${ }^{3}$ Milk yield during the first 7 wh of lactation.

${ }^{4} \mathrm{ECM}, \mathrm{CP}$, and fat yield, milk fat and protein percentage during wk 2 to 6 of lactation.

${ }^{5}$ Mean BW and BCS for the 6-wk pre- and postcalving period.

${ }^{6} \mathrm{BCS}$ on a 10-point scale, where 1 is emaciated and 10 is obese (Roche et al., 2004) during the 6-wk pre- and postcalving period.

reduced number of steps taken have been reported due to other diseases (Edwards and Tozer, 2004; Liboreiro et al., 2015; Barragan et al., 2018). Collectively, the literature indicates that "sick" cows walk less, perform other activities fewer times each day, and lie for longer.

\section{Lying Bouts as Sickness Behaviors}

To our knowledge, LB on d 0 have not been reported for cows experiencing hypocalcemia. We observed that cows in the NORM group had fewer LB $(16.3 \pm 0.72$ no./d) on d 0 than did cows in the SUB $(18.2 \pm 0.68$ no. $/ \mathrm{d} ; P<0.05)$ and CLIN groups $(19.2 \pm 0.69$ no. $/ \mathrm{d}$; $P<0.01$; Figure 2b), highlighting a potential effect of blood Ca status on this peripartum characteristic. In clinically healthy cows, LB increase substantially on the day of calving in both housed and grazing cows (Huzzey et al., 2005; Hendriks et al., 2019), and the increase in transitioning between lying and standing positions has been hypothesized to result from discomfort associated with calving, whereas the number of LB are reduced in ketotic compared with non-ketotic cows. Itle et al. (2015) speculated that ketotic cows may be less willing to engage in behaviors that are energetically expensive, therefore transitioning less frequently between lying and standing positions (Susenbeth et al., 2004). In contrast, in our study, cows experiencing clinical and subclinical hypocalcemia had more LB on d 0 than did normocalcemic cows. Although it is difficult to explain this increase in LB, Proudfoot et al. (2009) reported that cows with dystocia had a greater number of LB than did cows with eutocia and hypothesized that this may be indicative of greater pain. Calcium is important for smooth muscle function; hence, low blood Ca concentrations may prolong labor due to weak contractions (Murray et al., 2008; Jawor et al., 2012) and represent a risk factor for dystocia (Correa et al., 1993; López Bernal, 2003). Although no cows in our study experienced clinical dystocia and we do not have the data to support this hypothesis, it is plausible that SUB and CLIN cows in our study experienced more painful or prolonged labor without clinical dystocia, contributing to their increased number of LB on the day of calving.

In our study, cows were either subclinically or clinically hypocalcemic, but without paresis, and changes in lying behavior and activity were relatively short-lived, with no difference evident by d 3 postcalving. In other studies, where cows experienced subclinical disease, changes in behavior were also short-lived or small (Jawor et al., 2012; Sepúlveda-Varas et al., 2014; Liboreiro et al., 2015). It should be noted that, in our study, absolute values for the 3 blood Ca groups fell within 1 $\mathrm{h}$ of the range of postcalving lying times (range 7.5 to $8.5 \mathrm{~h} / \mathrm{d}$ ) reported as "normal" in literature (SepúlvedaVaras et al., 2014). The transient behavioral differences observed in our study and the lack of differences in blood $\mathrm{Ca}$ concentrations between the 3 blood $\mathrm{Ca}$ groups by $3 \mathrm{~d}$ postcalving reflect animals self-curing and restoring blood $\mathrm{Ca}$ to sufficient concentrations to overcome the debilitating effects of hypocalcemia. The 
severity of the disease may, in part, influence whether differences in behavior are evident after disease diagnosis (Sepúlveda-Varas et al., 2014), but our results indicate that, despite relatively small observed mean differences for the behavior measures reported, lying and walking behavior are associated with peripartum blood Ca status.

\section{Lying Behavior and Activity Within Day Associated with Blood Ca Status}

Mean sunrise and sunset times in both studies were 0725 and $1720 \mathrm{~h}$, respectively (Timeanddate.com, 2017). Maximal lying time and minimal steps taken coincided with periods of darkness (i.e., between 1800 and $0600 \mathrm{~h}$ ), irrespective of Ca status (Tables 3 and 4); this outcome is in agreement with other studies undertaken in grazing dairy cows (O'Connell et al., 1989; Sheahan et al., 2011). However, the difference between day and night activity was less for cows in the CLIN group, and therefore, the association between metabolic status and behavior was not diurnally homogeneous. On $\mathrm{d}-1$ precalving, the CLIN group tended to spend more time lying per hour $(P=0.10)$, due in part to a Ca status $\times$ time interval interaction $(P<0.05$; Table 3$)$. On the day of calving, a Ca status association with lying time $(P<0.01)$ indicates that, overall, cows in the CLIN group spent more time lying $(24.5 \pm 1.59 \mathrm{~min} / \mathrm{h})$ than did cows in the NORM and SUB groups (17.5 \pm 1.89 vs. $18.2 \pm 1.62 \mathrm{~min} / \mathrm{h}$, respectively; $P<0.05$ ). Temporal lying behavior and activity data indicate a Ca status $\times$ time interval interaction $(P<0.001$ and 0.01 , respectively; Tables 3 and 4 ), where during the early morning (between 0200 and $0600 \mathrm{~h}$ ) and daytime (between 1000 and $1400 \mathrm{~h}$ ) the CLIN group spent more time lying down $(P<0.05)$ and took fewer steps (between 1400 and $1800 \mathrm{~h} ; P<0.01)$ than the NORM and SUB groups did (Tables 3 and 4 ).

In our study, differences in lying time and activity for cows experiencing hypocalcemia were more promi-

Table 3. Mean lying time $(\mathrm{min} / \mathrm{h})$ across 4 -h time intervals on the day before calving ( $\mathrm{d}-1$ precalving), the day of calving ( $\mathrm{d}$ 0), and the day after calving (d 1 postcalving) in the 3 calcium groups (NORM, SUB, and CLIN $)^{1}$

\begin{tabular}{|c|c|c|c|c|c|c|c|}
\hline \multirow[b]{2}{*}{ Time interval, ${ }^{2} \mathrm{~h}$} & \multicolumn{6}{|c|}{ Mean (SEM) lying time, $\mathrm{min} / \mathrm{h}$} & \multirow[b]{2}{*}{$P$-value } \\
\hline & \multicolumn{2}{|c|}{ NORM } & \multicolumn{2}{|c|}{ SUB } & \multicolumn{2}{|c|}{ CLIN } & \\
\hline $\begin{array}{l}\mathrm{d}-1 \text { precalving } \\
02-05\end{array}$ & $414^{\mathrm{b}, \mathrm{w}}$ & $(209)$ & $405^{\mathrm{b}, \mathrm{w}}$ & & $484^{\mathrm{a}, \mathrm{w}}$ & & \\
\hline $\begin{array}{l}02-05 \\
06-09\end{array}$ & $8.03^{\mathrm{z}}$ & $(2.11)$ & $\begin{array}{l}40.5 \\
7.40^{y}\end{array}$ & $\begin{array}{l}(1.95) \\
(1.97)\end{array}$ & $\begin{array}{l}48.4 \\
8.73^{y}\end{array}$ & $\begin{array}{l}(1.92) \\
(1.95)\end{array}$ & $\begin{array}{r}<0.01 \\
0.89\end{array}$ \\
\hline $10-13$ & $6.30^{\mathrm{z}}$ & $(2.11)$ & $3.63^{\mathrm{y}}$ & $(1.97)$ & $8.03^{\mathrm{y}}$ & $(1.95)$ & 0.29 \\
\hline $14-17$ & $7.99^{\mathrm{z}}$ & $(2.10)$ & $6.26^{\mathrm{y}}$ & $(1.95)$ & $7.39^{y}$ & $(1.95)$ & 0.82 \\
\hline $18-21$ & $28.4^{\mathrm{a}, \mathrm{y}}$ & $(2.07)$ & $21.2^{\mathrm{b}, \mathrm{x}}$ & $(1.92)$ & $29.5^{\mathrm{a}, \mathrm{x}}$ & $(1.91)$ & $<0.01$ \\
\hline $22-01$ & $27.9^{\mathrm{x}}$ & $(2.04)$ & $31.3^{\mathrm{x}}$ & $(1.89)$ & $32.3^{\mathrm{x}}$ & $(1.86)$ & 0.26 \\
\hline$P$-value & $<0.001$ & & $<0.001$ & & $<0.001$ & & \\
\hline \multicolumn{8}{|l|}{ d 0} \\
\hline $02-05$ & $26.6^{\mathrm{b}, \mathrm{w}}$ & $(2.37)$ & $25.3^{\mathrm{b}, \mathrm{w}}$ & $(2.17)$ & $39.7^{\mathrm{a}, \mathrm{w}}$ & $(2.13)$ & $<0.001$ \\
\hline 06-09 & $8.95^{\mathrm{b}, \mathrm{y}}$ & $(2.42)$ & $11.4^{\mathrm{ab}, \mathrm{x}}$ & $(2.21)$ & $16.3^{\mathrm{a}, \mathrm{x}}$ & $(2.19)$ & 0.02 \\
\hline $10-13$ & $9.32^{\mathrm{b}, \mathrm{y}}$ & $(2.42)$ & $12.6^{\mathrm{b}, \mathrm{x}}$ & $(2.21)$ & $18.9^{\mathrm{a}, \mathrm{x}}$ & (2.19) & 0.01 \\
\hline $14-17$ & $4.85^{\mathrm{b}, \mathrm{y}}$ & $(2.42)$ & $7.24^{\mathrm{a}, \mathrm{y}}$ & $(2.21)$ & $16.6^{\mathrm{a}, \mathrm{x}}$ & $(2.19)$ & $<0.001$ \\
\hline $18-21$ & $28.6^{\mathrm{x}}$ & $(2.39)$ & $28.1^{\mathrm{w}}$ & $(2.18)$ & $28.3^{\mathrm{w}}$ & $(2.18)$ & 0.99 \\
\hline $22-01$ & $26.8^{\mathrm{x}}$ & $(2.37)$ & $24.4^{\mathrm{w}}$ & $(2.16)$ & $27.1^{\mathrm{w}}$ & $(2.12)$ & 0.63 \\
\hline$P$-value & $<0.001$ & & $<0.001$ & & $<0.001$ & & \\
\hline \multicolumn{8}{|l|}{ d 1 postcalving } \\
\hline $02-05$ & 37.8 & $(2.12)$ & 39.4 & $(1.97)$ & 38.4 & $(1.93)$ & 0.85 \\
\hline 06-09 & 4.39 & (2.19) & 5.90 & $(2.04)$ & 5.45 & $(2.03)$ & 0.87 \\
\hline $10-13$ & 14.9 & $(2.19)$ & 19.3 & $(2.04)$ & 17.8 & $(2.03)$ & 0.33 \\
\hline $14-17$ & 2.79 & (2.19) & 6.05 & $(2.04)$ & 6.90 & $(2.03)$ & 0.35 \\
\hline $18-21$ & 29.1 & $(2.18)$ & 27.8 & $(2.02)$ & 30.1 & $(2.01)$ & 0.71 \\
\hline $22-01$ & 25.5 & $(2.13)$ & 23.8 & $(1.98)$ & 26.0 & (1.98) & 0.71 \\
\hline$P$-value & $<0.001$ & & $<0.001$ & & $<0.001$ & & \\
\hline
\end{tabular}

${ }^{\mathrm{a}, \mathrm{b}}$ Means with different superscripts are significantly different at the $5 \%$ confidence level within a row (across groups).

${ }^{\mathrm{w}-\mathrm{z}}$ Means with different superscripts are significantly different at the $5 \%$ confidence level within a column (across time).

${ }^{1}$ Cows ( $\mathrm{n}=24$ per group) were classified as having clinical hypocalcemia (CLIN; blood $\mathrm{Ca} \leq 1.4 \mathrm{mmol} / \mathrm{L}$ within $48 \mathrm{~h}$ postcalving but without parturient paresis), subclinical hypocalcemia (SUB; blood Ca $>1.4$ and $<2.0 \mathrm{mmol} / \mathrm{L}$ within $48 \mathrm{~h}$ postcalving), or normocalcemia (NORM; blood $\mathrm{Ca} \geq 2.0 \mathrm{mmol} / \mathrm{L}$ within $72 \mathrm{~h}$ postcalving).

${ }^{2}$ Time intervals include data within each hour specified (e.g., 02-05 covers the period 0200 to $0559 \mathrm{~h}$ ). 
nent at certain times of the day and during certain periods relative to disease diagnosis, which is consistent with other studies investigating behavior associated with other diseases (Huzzey et al., 2007; Itle et al., 2015). Grazing dairy cows display behavioral synchrony (O'Connell et al., 1989), meaning they perform similar behavioral activities at the same time. Therefore, identifying cows that are lying down when most of the herd are standing grazing may be an alternative and novel approach to studying behavior in grazing dairy cows to detect cows at risk of, or with, a disease.

Similar to the daily lying and activity data presented, the differences in diurnal profiles were short-lived. We detected differences within day between Ca groups on the day before and the day of calving; however, no further differences were evident at 1 to $2 \mathrm{~d}$ postcalving. Prospective studies are needed to determine whether lying behavior and activity on the day of calving for individual cows could alert producers to a cow experiencing hypocalcemia.

\section{Lying Time and Activity as Early Indicators of Disease}

Behavioral changes as early indicators of disease have been documented in transition cows; however, research in grazing dairy cows is limited. On the day before calving, cows in the CLIN group spent $1.4 \mathrm{~h}$ longer lying down $(9.0 \pm 0.47 \mathrm{~h} / \mathrm{d} ; P<0.05)$ than cows in the SUB group $(7.4 \pm 0.46 \mathrm{~h} / \mathrm{d})$, which did not differ from cows in the NORM group $(7.8 \pm 0.49 \mathrm{~h} / \mathrm{d})$; however, no differences in lying behavior were evident before this (Figure 2a). This result contrasts with the study by Jawor et al. (2012), in which cows experiencing subclinical hypocalcemia were found to stand for $2.6 \mathrm{~h}$ longer than normocalcemic cows during the 24 -h period before parturition. The subclinically hypocalcemic cows in their study produced, on average, $6 \mathrm{~kg} / \mathrm{d}$ more milk during wk 2 to 4 ; therefore, those authors speculated that the greater standing time might be attributed to increased udder fill, which may have made lying down

Table 4. Mean number of steps (steps/h) across 4-h time intervals on the day before calving ( $\mathrm{d}-1$ precalving), the day of calving (d 0), and the day after calving (d 1 postcalving) in the 3 calcium groups ${ }^{1}$

\begin{tabular}{|c|c|c|c|c|c|c|c|}
\hline \multirow[b]{2}{*}{ Time interval, ${ }^{2} \mathrm{~h}$} & \multicolumn{6}{|c|}{ Mean (SEM) number of steps taken, steps/h } & \multirow[b]{2}{*}{$P$-value } \\
\hline & \multicolumn{2}{|c|}{ NORM } & \multicolumn{2}{|c|}{ SUB } & \multicolumn{2}{|c|}{ CLIN } & \\
\hline \multicolumn{8}{|l|}{$\mathrm{d}-1$ precalving } \\
\hline $02-05$ & $14^{\mathrm{y}}$ & (14) & $5^{\mathrm{x}}$ & (14) & $15^{\mathrm{w}}$ & (14) & 0.86 \\
\hline 06-09 & $195^{\mathrm{v}}$ & (15) & $180^{\mathrm{v}}$ & (14) & $191^{\mathrm{v}}$ & (14) & 0.76 \\
\hline $10-13$ & $176^{\mathrm{vw}}$ & (15) & $181^{\mathrm{v}}$ & (14) & $163^{\mathrm{v}}$ & (14) & 0.68 \\
\hline $14-17$ & $142^{\mathrm{w}}$ & (15) & $174^{\mathrm{v}}$ & (14) & $165^{\mathrm{v}}$ & (14) & 0.31 \\
\hline $18-21$ & $72^{x}$ & (15) & $71^{\mathrm{w}}$ & (14) & $55^{\mathrm{w}}$ & (14) & 0.64 \\
\hline $22-01$ & $54^{\mathrm{xy}}$ & $(15)$ & $41^{\mathrm{wx}}$ & $(14)$ & $47^{\mathrm{w}}$ & $(13)$ & 0.81 \\
\hline$P$-value & $<0.001$ & & $<0.001$ & & $<0.001$ & & \\
\hline \multicolumn{8}{|l|}{ d 0} \\
\hline $02-05$ & $43^{\mathrm{x}}$ & $(21)$ & $71^{y}$ & (19) & $39^{\mathrm{w}}$ & (19) & 0.48 \\
\hline 06-09 & $216^{\mathrm{w}}$ & $(22)$ & $155^{\mathrm{x}}$ & (20) & $181^{\mathrm{v}}$ & $(20)$ & 0.12 \\
\hline $10-13$ & $276^{\mathrm{a}, \mathrm{v}}$ & $(22)$ & $229^{\mathrm{ab}, \mathrm{w}}$ & $(20)$ & $200^{\mathrm{b}, \mathrm{v}}$ & $(20)$ & 0.04 \\
\hline $14-17$ & $317^{\mathrm{a}, \mathrm{v}}$ & $(22)$ & $286^{\mathrm{b}, \mathrm{v}}$ & $(20)$ & $207^{\mathrm{b}, \mathrm{v}}$ & $(20)$ & $<0.001$ \\
\hline $18-21$ & $85^{\mathrm{x}}$ & (21) & $54^{\mathrm{y}}$ & $(20)$ & $65^{\mathrm{w}}$ & $(20)$ & 0.56 \\
\hline $22-01$ & $87^{\mathrm{x}}$ & (21) & $91^{\mathrm{y}}$ & (19) & $68^{\mathrm{w}}$ & (19) & 0.69 \\
\hline$P$-value & $<0.001$ & & $<0.001$ & & $<0.001$ & & \\
\hline \multicolumn{8}{|l|}{ d 1 postcalving } \\
\hline $02-05$ & $21^{\mathrm{z}}$ & (19) & $21^{\mathrm{x}}$ & $(18)$ & $31^{\mathrm{z}}$ & (17) & 0.91 \\
\hline $06-09$ & $300^{\mathrm{a}, \mathrm{w}}$ & $(20)$ & $345^{\mathrm{a}, \mathrm{v}}$ & $(18)$ & $237^{\mathrm{b}, \mathrm{w}}$ & $(18)$ & $<0.001$ \\
\hline $10-13$ & $174^{\mathrm{a}, \mathrm{x}}$ & $(20)$ & $101^{\mathrm{b}, \mathrm{w}}$ & (18) & $176^{\mathrm{a}, \mathrm{x}}$ & (18) & $<0.01$ \\
\hline $14-17$ & $350^{\mathrm{v}}$ & $(20)$ & $323^{\mathrm{v}}$ & (18) & $303^{\mathrm{v}}$ & (18) & 0.22 \\
\hline $18-21$ & $41^{\mathrm{yz}}$ & (20) & $51^{\mathrm{x}}$ & (18) & $74^{\mathrm{y}}$ & (18) & 0.45 \\
\hline $22-01$ & $77^{\mathrm{y}}$ & (19) & $89^{\mathrm{w}}$ & (18) & $83^{\mathrm{y}}$ & (18) & 0.90 \\
\hline$P$-value & $<0.001$ & & $<0.001$ & & $<0.001$ & & \\
\hline
\end{tabular}

\footnotetext{
${ }^{\mathrm{a}, \mathrm{b}}$ Means with different superscripts are significantly different at the $5 \%$ confidence level within a row (across groups).

${ }^{\mathrm{v}-\mathrm{Z}}$ Means with difference superscripts are significantly different at the $5 \%$ confidence level within a column (across time).

${ }^{1}$ Cows $(\mathrm{n}=24$ per group) were classified as having clinical hypocalcemia (CLIN; blood $\mathrm{Ca} \leq 1.4 \mathrm{mmol} / \mathrm{L}$ within $48 \mathrm{~h}$ postcalving but without parturient paresis), subclinical hypocalcemia (SUB; blood Ca $>1.4$ and $<2.0 \mathrm{mmol} / \mathrm{L}$ within $48 \mathrm{~h}$ postcalving), or normocalcemia (NORM; blood $\mathrm{Ca}>2.0 \mathrm{mmol} / \mathrm{L}$ within $72 \mathrm{~h}$ postcalving).

${ }^{2}$ Time intervals include data within each hour specified (e.g., 02-05 covers the period 0200 to $0559 \mathrm{~h}$ ).
} 
more uncomfortable. In contrast, we hypothesize that the increase in lying time in CLIN cows in our study may be attributed to weak skeletal muscle contractility, which could reduce the desire to stand (Murray et al., 2008). It is not possible to determine whether other stressors or modifications in lying behavior predisposed cows to hypocalcemia, or whether increased time spent lying down is indicative of a change in behavior caused by hypocalcemia (Proudfoot and Huzzey, 2017). Nevertheless, our data indicate a change in behavior preceding the hypocalcemic event, which suggests that lying and activity measures could be early indicators of this disease.

\section{Modeling Early Indicators of Disease Within Cow}

Due to large cow-to-cow variation, a review of behavior and health of transition cows by Proudfoot and Huzzey (2017) recommended that future work focus on studying within-cow changes, as these are likely to be more sensitive than absolute values for detecting changes in behavior due to ill health (Ito et al., 2009). Relative changes in behavior within cow, for example, is the measure of choice for estrus detection (Silper et al., 2015). To further improve our understanding of within-cow changes in behavior over time, we investigated linear and nonlinear associations between relative change in behavior [from a baseline period (either -21 or -14 to $-7 \mathrm{~d}$ precalving) to $\mathrm{d}-1$ or $\mathrm{d} 0$ ] and blood Ca concentrations within $24 \mathrm{~h}$ postcalving. Correlations for the aforementioned periods investigated are presented in Supplemental Table S3 (https://doi.org/ 10.3168/jds.2019-18111). During the preliminary stages of our analysis, we also investigated the associations between mean daily lying time and number of steps taken on d 0 and blood Ca concentrations within $24 \mathrm{~h}$ postcalving (data not presented). However, we detected the strongest relationships for models investigating the change in daily and hourly daytime lying behavior and activity relative to $\mathrm{d} 0$; therefore, we presented these models. Several studies indicate that changes in lying behavior (e.g., lying time and LB) may be disease-dependent, with increased (Sepúlveda-Varas et al., 2014) or decreased lying behavior (Itle et al., 2015), or both, reported due to disease (Jawor et al., 2012).

\section{Linear and Nonlinear Associations}

In the current study, the change in lying time from a baseline period ( $\mathrm{d}-14$ to -7 precalving) to $\mathrm{d} 0$ had negative linear and nonlinear associations with blood Ca concentration within $24 \mathrm{~h}$ postcalving $(P<0.02)$. The final model, which also included calvingseasonday and parity, explained $39 \%$ of the variation (Table 5).
In addition, the change in hourly lying time during the day (between 0600 and $1800 \mathrm{~h}$ ) from a baseline period (d -14 to -7 precalving) until d 0 had a negative linear association with blood $\mathrm{Ca}$ concentration within $24 \mathrm{~h}$ postcalving $(P<0.01)$, and the final model explained $41 \%$ of the variation (Table 6 ). A relative 5 -min increase in mean lying time per $\mathrm{h}$ during the day on $\mathrm{d}$ 0 compared with the baseline period was associated with a decrease in blood Ca concentration within $24 \mathrm{~h}$ postcalving of $0.09 \mathrm{mmol} / \mathrm{L}$ (Table 6). Change in daily steps taken from a baseline period (d -14 to -7 precalving) to d 0 was also associated with blood Ca concentration within $24 \mathrm{~h}$ postcalving $(P<0.05)$, and the final model explained $36 \%$ of the variation (Table 5 ). A relative increase of 1,000 steps/d on d 0 compared with the baseline period was associated with an increase in blood Ca concentration of $0.07 \mathrm{mmol} / \mathrm{L}$ within $24 \mathrm{~h}$ postcalving. Parity was an important associated factor in these models, which is unsurprising, considering the well-known association of hypocalcemia with increasing age (Horst et al., 1997).

Our results indicate that behavioral measures, such as relative change in daily and hourly daytime lying time and activity compared with a baseline period before calving, the time of day the behavior is recorded, and the magnitude of change within cow at calving, may provide useful information for the early identification of hypocalcemia. Whether these changes in behavior are caused by hypocalcemia or predispose cows to develop hypocalcemia is not known (Proudfoot and Huzzey, 2017). Understanding the drivers of the behavioral changes identified in our study has the potential to improve our understanding of cause-and-effect relationships for transition cow disease and improve the identification and prevention of hypocalcemia on-farm. Future work should consider a prediction modeling or machine-based learning approach to explore the potential to detect hypocalcemia and other transition cow diseases in individual cows.

\section{Differences in Metabolic Indices and Milk Production Associated with Blood Ca Status}

In our study, average milk yield for the first $7 \mathrm{wk}$ of lactation did not differ between blood Ca status groups (Table 2); however, a tendency occurred $(P=0.06)$ for a Ca status $\times$ week interaction (Figure 3 ). Further, no associations were detected between Ca status and ECM, $\mathrm{CP}$ yield, fat yield, milk fat\%, or protein\% (Table 2), nor any Ca status $\times$ week interactions for ECM yield and milk fat $\%(P=0.67$ and 0.84 , respectively; Figure 4a) during wk 2 to 6 of lactation. A tendency for a Ca status $\times$ week interaction for $\mathrm{CP}$ yield $(P=0.07)$ was driven by temporal changes. A Ca status $\times$ week 
Table 5. Regression coefficient for change $(\Delta)$ in daily lying time $(\mathrm{h} / \mathrm{d})$ and change in daily number of steps taken (steps/d) from a baseline period (d -14 to -7 precalving) until the day of calving (d 0 ) and associations with blood calcium (mmol/L) within $24 \mathrm{~h}$ postcalving, adjusted for group, calving season day (calvingseasonday), and parity

\begin{tabular}{|c|c|c|c|c|c|}
\hline \multirow[b]{2}{*}{ Blood $\mathrm{Ca},{ }^{1} \mathrm{mmol} / \mathrm{L}$ (24 h postcalving) } & \multirow[b]{2}{*}{ Estimate } & \multirow[b]{2}{*}{ SE } & \multicolumn{2}{|c|}{$95 \%$ confidence limits } & \multirow[b]{2}{*}{$P$-value } \\
\hline & & & Lower & Upper & \\
\hline \multicolumn{6}{|l|}{$\Delta$ Daily lying time model } \\
\hline Intercept & 1.55 & 0.27 & 1.00 & 2.09 & $<0.001$ \\
\hline Calvingseasonday $^{2}$ & 0.005 & 0.005 & -0.004 & 0.014 & 0.297 \\
\hline Parity $2-3^{3}$ & 0.35 & 0.13 & 0.08 & 0.62 & 0.012 \\
\hline Parity $4+{\text { (reference group })^{3}}^{3}$ & 0.00 & - & - & - & - \\
\hline Linear ( $\Delta$ daily lying time), $\mathrm{h} / \mathrm{d}$ & -0.08 & 0.03 & -0.14 & -0.02 & 0.006 \\
\hline Quadratic ( $\Delta$ daily lying time), $\mathrm{h} / \mathrm{d}$ & -0.008 & 0.004 & -0.016 & 0.0002 & 0.015 \\
\hline $\mathrm{R}^{2}$ & 0.39 & & & & \\
\hline \multicolumn{6}{|l|}{$\Delta$ Daily steps model } \\
\hline Intercept & 1.50 & 0.28 & 0.94 & 2.06 & $<0.001$ \\
\hline Calvingseasonday $^{2}$ & 0.006 & 0.005 & -0.004 & 0.015 & 0.237 \\
\hline Parity $2-3^{3}$ & 0.35 & 0.14 & 0.07 & 0.63 & 0.017 \\
\hline Parity $4+{\text { (reference group })^{3}}^{2}$ & 0.00 & - & - & - & - \\
\hline$\Delta$ Daily steps per 1,000 units,${ }^{4}$ steps $/ \mathrm{d}$ & 0.07 & 0.03 & $0.40\left(\times 10^{2}\right)$ & 0.13 & 0.038 \\
\hline $\mathrm{R}^{2}$ & 0.36 & & & & \\
\hline
\end{tabular}

${ }^{1}$ Estimates for study group are not included to avoid cluttering the table. In total, 12 groups were included in the analysis to investigate associations after adjusting for study group (treatment within study differences).

${ }^{2}$ Calvingseasonday $=$ difference between calving date and June 1 , in days, within the herd.

${ }^{3}$ Parity $2-3=$ cows approaching their second or third parity at the time of calving; parity $4+=$ cows approaching their fourth, fifth, sixth, or seventh parity at the time of calving. Parity $4+$ is the reference group for parity effects; $P<0.05$; slope is different from reference group for classification variable.

${ }^{4}$ Steps taken per 1,000-unit increase.

interaction was detectable for milk protein percentage $(P<0.01)$, where the CLIN group had a greater $(P<$ $0.05)$ milk protein percentage at 2 wk in milk than did the SUB and NORM groups, which were not different from each other, but no further differences appeared between the groups beyond 2 wk in milk (Figure $4 \mathrm{~b}$ ). Body condition score and BW profiles describing preto postcalving periods are presented in Figures 5a and

Table 6. Regression coefficient for change $(\Delta)$ in hourly daytime lying time $(\mathrm{min} / \mathrm{h})$ and change in hourly daytime number of steps taken (steps/h, between 0600 and $1800 \mathrm{~h}$ ) from a baseline period $(\mathrm{d}-14$ to -7 precalving) until the day of calving (d 0) and associations with blood calcium (mmol/L) within $24 \mathrm{~h}$ postcalving, adjusted for group, calving season day (calvingseasonday), and parity

\begin{tabular}{|c|c|c|c|c|c|}
\hline \multirow[b]{2}{*}{ Blood $\mathrm{Ca},{ }^{1} \mathrm{mmol} / \mathrm{L}$ (24 h postcalving) } & \multirow[b]{2}{*}{ Estimate } & \multirow[b]{2}{*}{$\mathrm{SE}$} & \multicolumn{2}{|c|}{$95 \%$ confidence limits } & \multirow[b]{2}{*}{$P$-value } \\
\hline & & & Lower & Upper & \\
\hline \multicolumn{6}{|l|}{$\Delta$ Hourly daytime lying model } \\
\hline Intercept & 1.60 & 0.29 & 1.02 & 2.18 & $<0.001$ \\
\hline Calvingseasonday $^{2}$ & 0.006 & 0.005 & -0.003 & 0.02 & 0.179 \\
\hline Parity $2-3^{3}$ & 0.38 & 0.13 & 0.12 & 0.64 & 0.005 \\
\hline Parity $4+{\text { (reference group })^{3}}^{3}$ & 0.00 & - & — & - & - \\
\hline$\Delta$ Hourly day lying time, $\mathrm{min} / \mathrm{h}$ & -0.02 & 0.006 & -0.03 & -0.006 & 0.003 \\
\hline \multicolumn{6}{|l|}{$\Delta$ Hourly daytime steps model } \\
\hline Intercept & 1.51 & 0.30 & 0.91 & 2.11 & $<0.001$ \\
\hline Calvingseasonday $^{2}$ & 0.005 & 0.005 & -0.005 & 0.02 & 0.306 \\
\hline Parity: $2-3^{3}$ & 0.38 & 0.14 & 0.10 & 0.66 & 0.008 \\
\hline Parity: $4+{\text { (reference group })^{3}}^{3}$ & 0.00 & - & - & - & - \\
\hline$\Delta$ Hourly daytime steps, steps $/ \mathrm{h}$ & 0.001 & 0.0005 & $0.18\left(\times 10^{4}\right)$ & 0.002 & $<0.05$ \\
\hline $\mathrm{R}^{2}$ & 0.35 & & & & \\
\hline
\end{tabular}

${ }^{1}$ Estimates for study group are not included to avoid cluttering the table. In total, 12 groups were included in the analysis to investigate associations after adjusting for study group (treatment within study differences). ${ }^{2}$ Calvingseasonday $=$ difference between calving date and June 1 , in days, within the herd.

${ }^{3}$ Parity $2-3=$ cows approaching their second or third parity at the time of calving; parity $4+=$ cows approaching their fourth, fifth, sixth, or seventh parity at the time of calving. Parity $4+$ is the reference group for parity effects; $P<0.05$; slope is different from reference group for classification variable. 


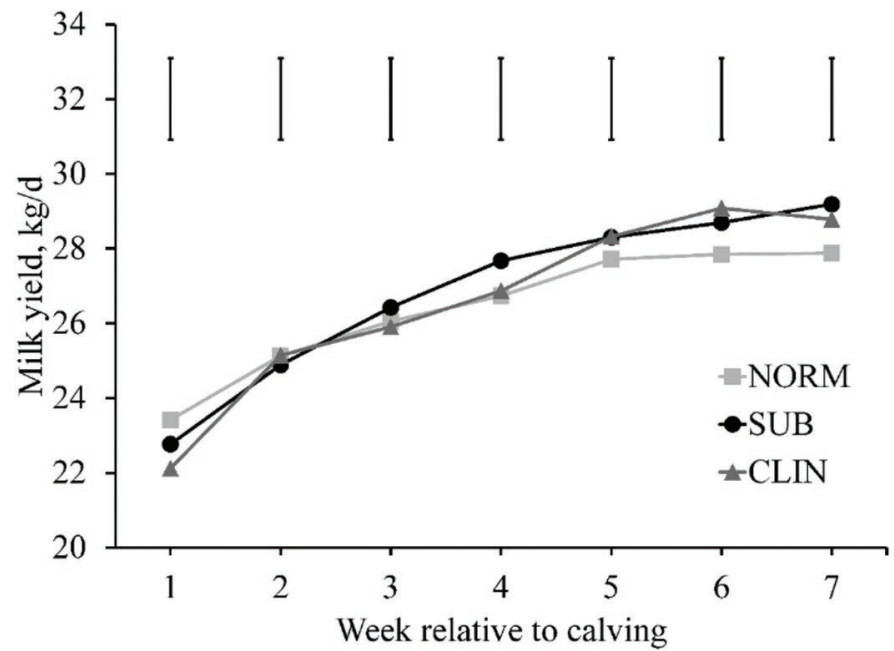

Figure 3. Milk yield $(\mathrm{kg} / \mathrm{d})$ during the first $7 \mathrm{wk}$ of lactation for the $3 \mathrm{Ca}$ groups. CLIN = clinical hypocalcemia (blood $\mathrm{Ca} \leq 1.4$ $\mathrm{mmol} / \mathrm{L}$ within $48 \mathrm{~h}$ postcalving); SUB $=$ subclinical hypocalcemia (blood $\mathrm{Ca}>1.4$ and $<2.0 \mathrm{mmol} / \mathrm{L}$ within $48 \mathrm{~h}$ postcalving); NORM = normocalcemia (blood $\mathrm{Ca} \geq 2.0 \mathrm{mmol} / \mathrm{L}$ within $72 \mathrm{~h}$ postcalving). Error bars represent $2 \times$ mean $\mathrm{SE}$ of the difference.

b. We detected no associations with Ca status (Table $2)$, nor Ca status $\times$ week interactions $(P=0.23$ and 0.98 , respectively).

In our study, mean blood NEFA and BHB were not different between the 3 Ca groups $(P=0.46$ and 0.14 , respectively). A Ca status $\times$ period interaction was detectable for blood NEFA concentrations $(P<0.05)$ driven by temporal changes (Figure 6a); however, no differences occurred between the $3 \mathrm{Ca}$ groups within each time period. Further, we detected no Ca status $\times$ period association on blood BHB concentration $(P=$ 0.16; Figure 6b). Greater blood NEFA concentrations indicate that cows were in negative energy balance commonly experienced during early lactation; however, their blood BHB concentrations were well below the $>1.0$ to $1.4 \mathrm{mmol} / \mathrm{L}$ thresholds typically used to indicate hyperketonemia (Oetzel, 2004).

In the current study, no associations were detected between hypocalcemia and milk production, metabolic indices, BCS, and BW measures; however, cows within each category were balanced according to genetic potential for milk protein yield, BW on wk -5 to -6 precalving, and parity to try to isolate any causal relationship between blood Ca status and cow behavior (Jawor et al., 2012). Our results, therefore, do not support a causal link between peripartum blood $\mathrm{Ca}$ status and milk production in non-paretic cows. Despite the lack of association between hypocalcemia and metabolic health in our study, cows with subclinical hypocalcemia are more at risk of being removed from the herd or experiencing another disease event (Chapinal et al., 2011; a)

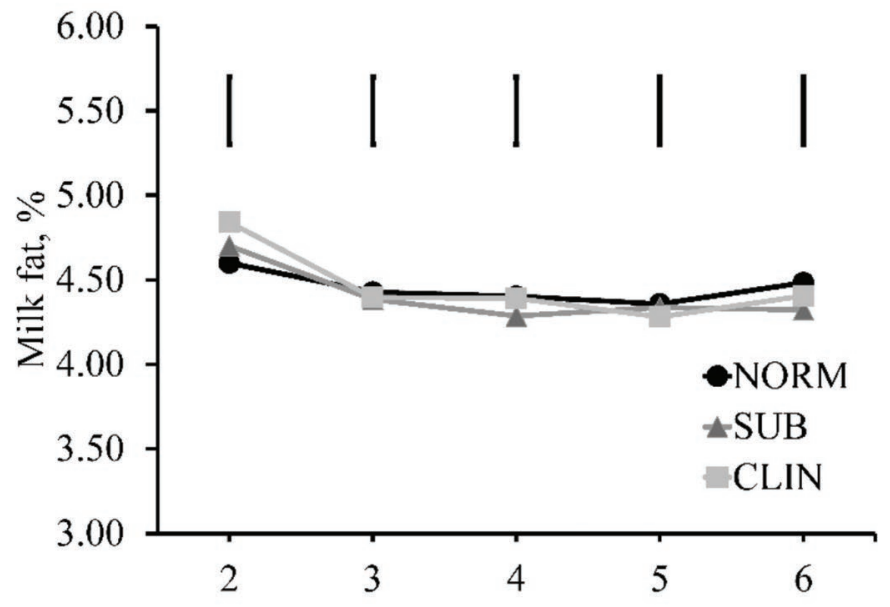

b)

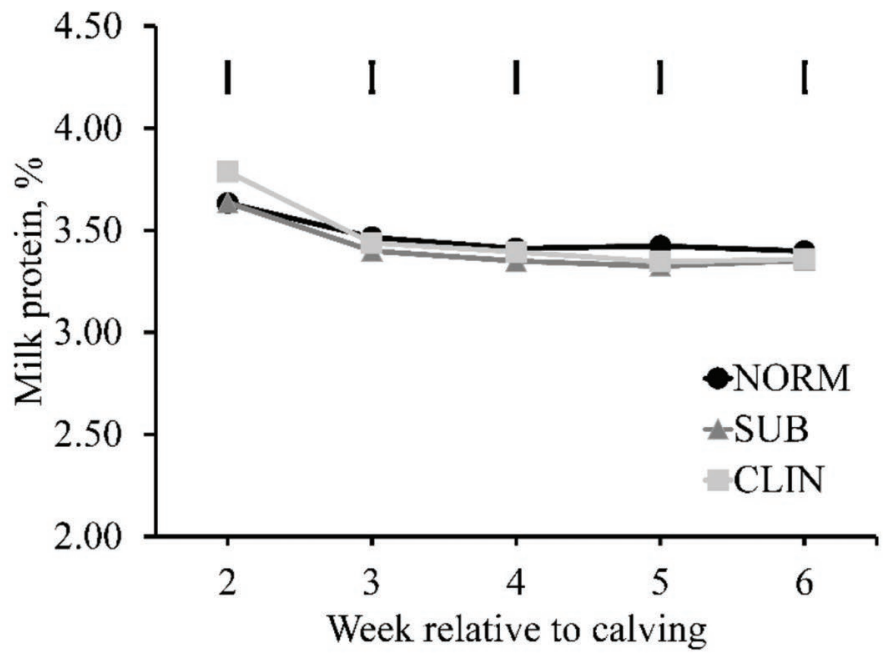

Figure 4. Milk fat (a, \%) and protein (b, \%) during wk 2 to 6 of lactation for the $3 \mathrm{Ca}$ groups. CLIN = clinical hypocalcemia (blood $\mathrm{Ca} \leq 1.4 \mathrm{mmol} / \mathrm{L}$ within $48 \mathrm{~h}$ postcalving); $\mathrm{SUB}=$ subclinical hypocalcemia (blood $\mathrm{Ca}>1.4$ and $<2.0 \mathrm{mmol} / \mathrm{L}$ within $48 \mathrm{~h}$ postcalving); $\mathrm{NORM}=$ normocalcemia $($ blood $\mathrm{Ca} \geq 2.0 \mathrm{mmol} / \mathrm{L}$ within $72 \mathrm{~h}$ postcalving). Error bars represent $2 \times$ mean $\mathrm{SE}$ of the difference.

McArt and Neves, 2020). Our data set was not large enough to evaluate this association, but if true, easily applied technology for identifying subclinically affected cows could be used to help better manage cow health and improve cow longevity, both important attributes in cow welfare.

\section{CONCLUSIONS}

We have characterized the behavioral differences before, at the time of, and after calving in groups of grazing dairy cows categorized with varying degrees 
a)

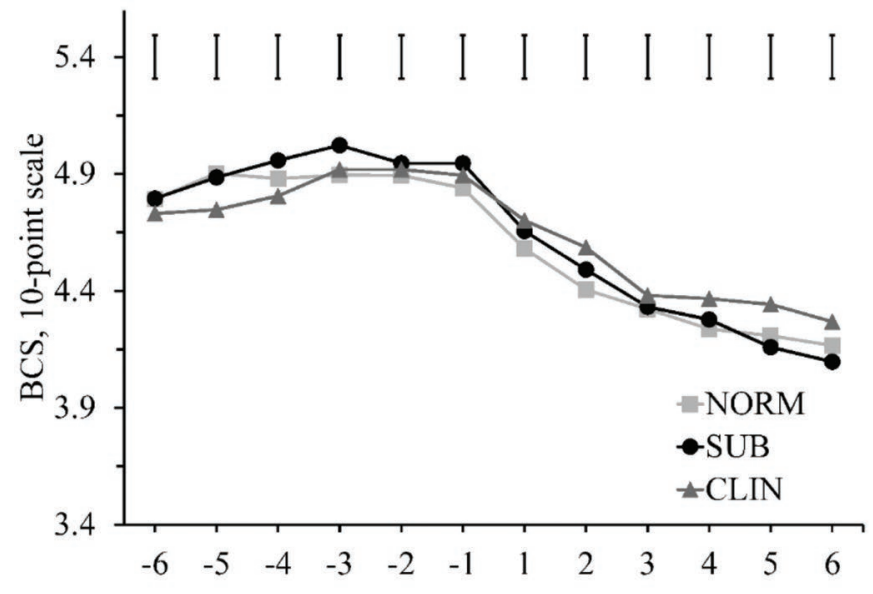

b)

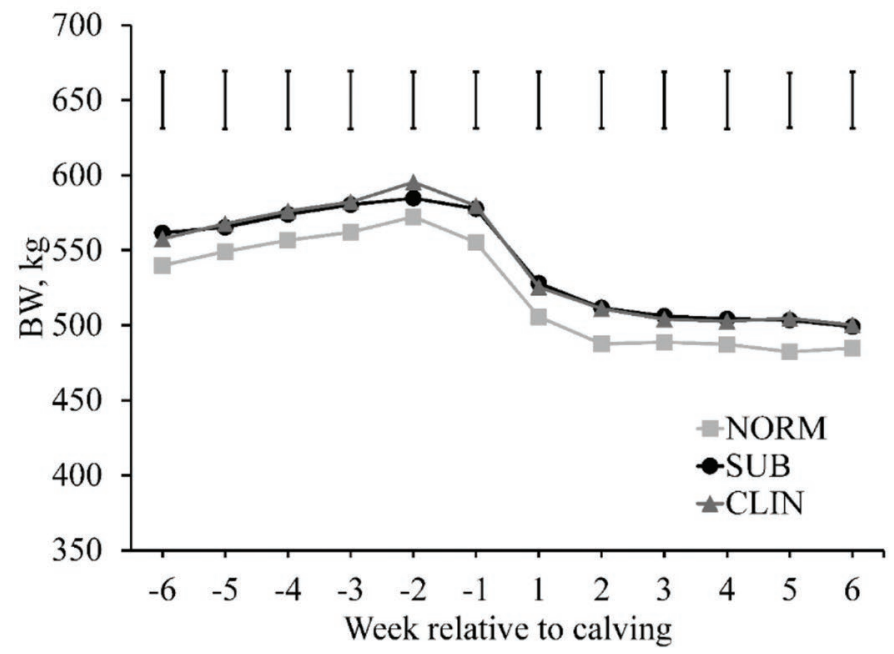

Figure 5. Mean BCS (a, 10-point scale, where 1 is emaciated and 10 is obese; Roche et al., 2004) and BW (b, kg) during the 6 wk preand postcalving for the 3 Ca groups. CLIN = clinical hypocalcemia (blood $\mathrm{Ca}<1.4 \mathrm{mmol} / \mathrm{L}$ within $48 \mathrm{~h}$ postcalving); $\mathrm{SUB}=$ subclinical hypocalcemia (blood $\mathrm{Ca}>1.4$ and $<2.0 \mathrm{mmol} / \mathrm{L}$ within $48 \mathrm{~h}$ postcalving); $\mathrm{NORM}=$ normocalcemia (blood $\mathrm{Ca} \geq 2.0 \mathrm{mmol} / \mathrm{L}$ within $72 \mathrm{~h}$ postcalving). Error bars represent $2 \times$ mean SE of the difference.

of hypocalcemia. Groups of cows experiencing clinical hypocalcemia without paresis were less active on the day of calving, spent more time lying, and had more LB compared with groups of cows categorized as subclinically hypocalcemic or normocalcemic. Cows in the clinically hypocalcemic group also spent more time lying down during hours of darkness on the day before calving. Changes in behavior were short-lived, as differences were no longer present by $2 \mathrm{~d}$ postcalving. Behavioral changes also occurred before calving, where a)

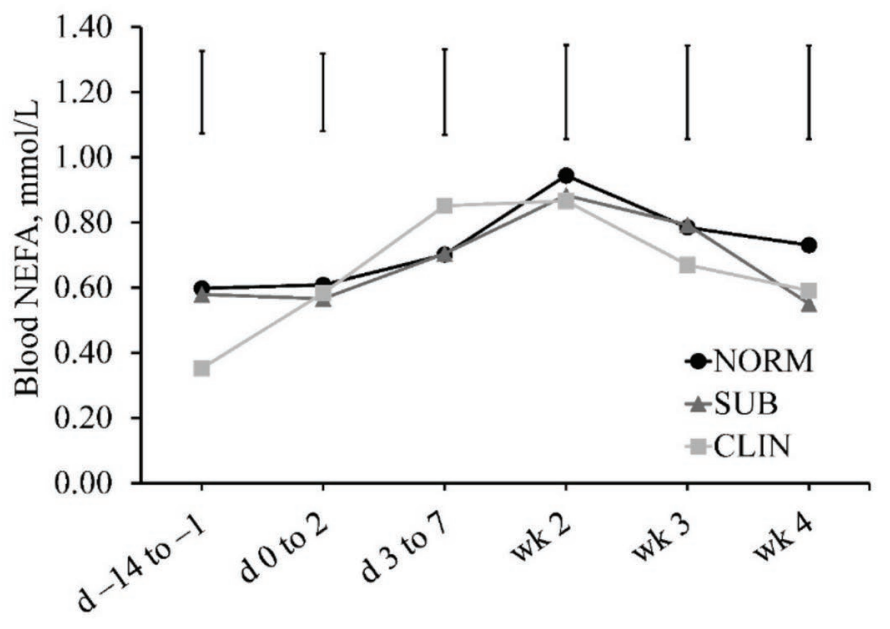

b)

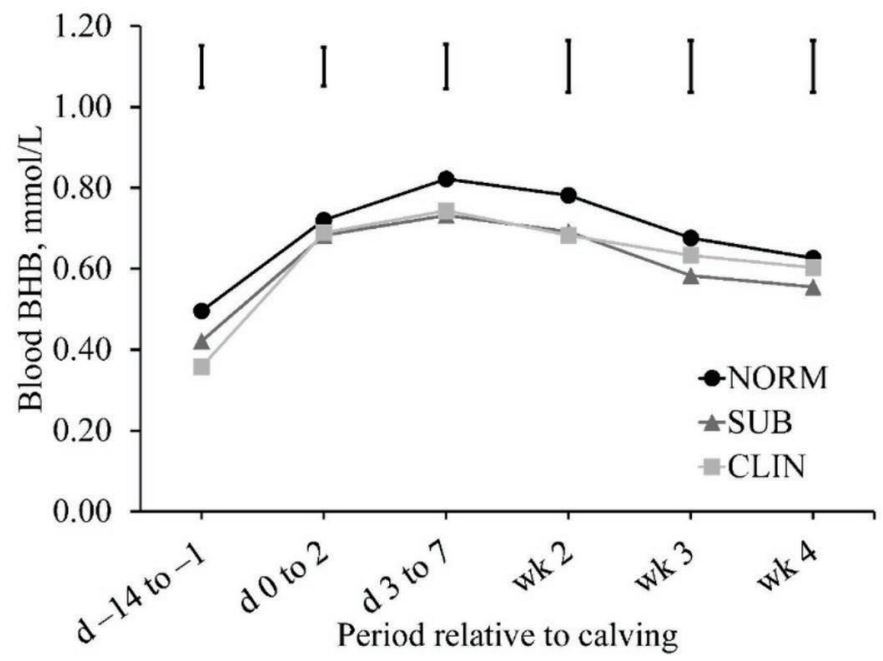

Figure 6. Blood nonesterified fatty acid (NEFA, a) and BHB (b) concentrations $(\mathrm{mmol} / \mathrm{L})$ during $\mathrm{d}-14$ to -1 precalving, d 0 to 2 postcalving, d 3 to 7 postcalving, and wk 2 to 4 postcalving for the 3 Ca groups. CLIN = clinical hypocalcemia (blood $\mathrm{Ca} \leq 1.4 \mathrm{mmol} / \mathrm{L}$ within $48 \mathrm{~h}$ postcalving); $\mathrm{SUB}=$ subclinical hypocalcemia (blood $\mathrm{Ca}$ $>1.4$ and $<2.0 \mathrm{mmol} / \mathrm{L}$ within $48 \mathrm{~h}$ postcalving); $\mathrm{NORM}=$ normocalcemia (blood $\mathrm{Ca} \geq 2.0 \mathrm{mmol} / \mathrm{L}$ within $72 \mathrm{~h}$ postcalving). Error bars represent $2 \times$ mean $\mathrm{SE}$ of the difference.

relative change in steps taken from a 2 -wk baseline before calving had a positive linear association with blood $\mathrm{Ca}$ concentration around the time of calving. Our results indicate that hypocalcemic cows, on average, exhibit behavioral characteristics different than normocalcemic cows, but further research is required to determine whether these differences have predictive potential at the individual cow level. 


\section{ACKNOWLEDGMENTS}

This work was funded by New Zealand dairy farmers through DairyNZ Inc. (Hamilton, New Zealand; project number RD1405) and by the Ministry of Business, Innovation and Employment (Wellington, New Zealand; contract numbers DRCX1302 and DRCX1201). S. Hendriks is also supported by the Colin Holmes Dairy Scholarship (Hamilton, New Zealand) and the Ministry for Primary Industries Postgraduate Scholarship (Wellington, New Zealand). The authors have not stated any conflicts of interest.

\section{REFERENCES}

Barragan, A. A., J. M. Pineiro, G. M. Schuenemann, P. J. RajalaSchultz, D. E. Sanders, J. Lakritz, and S. Bas. 2018. Assessment of daily activity patterns and biomarkers of pain, inflammation, and stress in lactating dairy cows diagnosed with clinical metritis. J. Dairy Sci. 101:8248-8258. https://doi.org/10.3168/jds.2018-14510.

Borchers, M. R., Y. M. Chang, K. L. Proudfoot, B. A. Wadsworth, A E. Stone, and J. M. Bewley. 2017. Machine-learning-based calving prediction from activity, lying, and ruminating behaviors in dairy cattle. J. Dairy Sci. 100:5664-5674. https://doi.org/10.3168/jds .2016-11526.

Chapinal, N., M. Carson, T. F. Duffield, M. Capel, S. Godden, M. Overton, J. E. Santos, and S. J. LeBlanc. 2011. The association of serum metabolites with clinical disease during the transition period. J. Dairy Sci. 94:4897-4903. https://doi.org/10.3168/jds $.2010-4075$.

Correa, M. T., H. Erb, and J. Scarlett. 1993. Path analysis for seven postpartum disorders of Holstein cows. J. Dairy Sci. 76:1305-1312. https://doi.org/10.3168/jds.S0022-0302(93)77461-5.

DairyNZ. 2018. Breeding worth explained. Accessed Aug. 13, 2019. https://www.dairynz.co.nz/media/532701/BW_explained.pdf.

Dantzer, R., and K. W. Kelley. 2007. Twenty years of research on cytokine-induced sickness behavior. Brain Behav. Immun. 21:153-160. https://doi.org/10.1016/j.bbi.2006.09.006.

DeGaris, P. J., and I. J. Lean. 2008. Milk fever in dairy cows: A review of pathophysiology and control principles. Vet. J. 176:58-69. https: //doi.org/10.1016/j.tvjl.2007.12.029.

Edwards, J. L., and P. R. Tozer. 2004. Using activity and milk yield as predictors of fresh cow disorders. J. Dairy Sci. 87:524-531. https:/ /doi.org/10.3168/jds.S0022-0302(04)73192-6.

Fitzpatrick, J. L., A. M. Nolam, E. M. Scott, L. S. Harkins, and D. C. Barrett. 2002. Observers perceptions of pain in cattle. Cattle Pract. 10:209-212.

Fogsgaard, K. K., C. M. Rontved, P. Sorensen, and M. S. Herskin. 2012. Sickness behavior in dairy cows during Escherichia coli mastitis. J. Dairy Sci. 95:630-638. https://doi.org/10.3168/jds.2011 -4350 .

Gambra, R., F. Penagaricano, J. Kropp, K. Khateeb, K. A. Weigel, J. Lucey, and H. Khatib. 2013. Genomic architecture of bovine א-casein and $\beta$-lactoglobulin. J. Dairy Sci. 96:5333-5343. https:// doi.org/10.3168/jds.2012-6324.

Goff, J. P. 1999. Treatment of calcium, phosphorus, and magnesium balance disorders. Vet. Clin. North Am. Food Anim. Pract. 15:619-639. https://doi.org/10.1016/S0749-0720(15)30167-5.

Goff, J. P. 2008. The monitoring, prevention, and treatment of milk fever and subclinical hypocalcemia in dairy cows. Vet. J. 176:50-57. https://doi.org/10.1016/j.tvjl.2007.12.020.

Hart, B. L. 1988. Biological basis of the behavior of sick animals. Neurosci. Biobehav. Rev. 12:123-137. https://doi.org/10.1016/S0149 -7634(88)80004-6.

Hendriks, S. J., C. V. C. Phyn, S.-A. Turner, K. M. Mueller, B. KuhnSherlock, D. J. Donaghy, J. M. Huzzey, and J. R. Roche. 2019. Lying behavior and activity during the transition period of clinically healthy grazing dairy cows. J. Dairy Sci. 102:7371-7384. https:// doi.org/10.3168/jds.2018-16045.

Horst, R. L., J. P. Goff, and T. A. Reinhardt. 1994. Calcium and vitamin D metabolism in the dairy cow. J. Dairy Sci. 77:1936-1951. https://doi.org/10.3168/jds.S0022-0302(94)77140-X.

Horst, R. L., J. P. Goff, T. A. Reinhardt, and D. R. Buxton. 1997. Strategies for preventing milk fever in dairy cattle. J. Dairy Sci. 80:1269-1280. https://doi.org/10.3168/jds.S0022-0302(97)76056 $-9$.

Huzzey, J. M., D. M. Veira, D. M. Weary, and M. A. G. Von Keyserlingk. 2007. Prepartum behavior and dry matter intake identify dairy cows at risk for metritis. J. Dairy Sci. 90:3220-3233. https:/ /doi.org/10.3168/jds.2006-807.

Huzzey, J. M., M. A. G. von Keyserlingk, and D. M. Weary. 2005. Changes in feeding, drinking, and standing behavior of dairy cows during the transition period. J. Dairy Sci. 88:2454-2461. https:// doi.org/10.3168/jds.S0022-0302(05)72923-4.

Itle, A. J., J. M. Huzzey, D. M. Weary, and M. A. G. von Keyserlingk. 2015. Clinical ketosis and standing behavior in transition cows. J. Dairy Sci. 98:128-134. https://doi.org/10.3168/jds.2014-7932.

Ito, K., D. M. Weary, and M. A. G. von Keyserlingk. 2009. Lying behavior: Assessing within- and between-herd variation in free-stallhoused dairy cows. J. Dairy Sci. 92:4412-4420. https://doi.org/10 $.3168 /$ jds.2009-2235.

Jawor, P. E., J. M. Huzzey, S. J. LeBlanc, and M. A. G. von Keyserlingk. 2012. Associations of subclinical hypocalcemia at calving with milk yield, and feeding, drinking, and standing behaviors around parturition in Holstein cows. J. Dairy Sci. 95:1240-1248. https://doi.org/10.3168/jds.2011-4586.

Johnson, R. W. 2002. The concept of sickness behavior: A brief chronological account of four key discoveries. Vet. Immunol. Immunopathol. 87:443-450. https://doi.org/10.1016/S0165-2427(02)00069 -7 .

Johnson, T., K. Eketone, L. McNaughton, K. Tiplady, J. Voogt, R. Sherlock, G. Anderson, M. Keehan, S. R. Davis, R. J. Spelman, D. Chin, and C. Couldrey. 2018. Mating strategies to maximize genetic merit in dairy cattle herds. J. Dairy Sci. 101:4650-4659. https://doi.org/10.3168/jds.2017-13538.

Kaufman, E. I., S. J. LeBlanc, B. W. McBride, T. F. Duffield, and T. J. DeVries. 2016. Short communication: Association of lying behavior and subclinical ketosis in transition dairy cows. J. Dairy Sci. 99:7473-7480. https://doi.org/10.3168/jds.2016-11185.

Kok, A., A. T. M. van Knegsel, C. E. van Middelaar, H. Hogeveen, B. Kemp, and I. J. M. de Boer. 2015. Technical note: Validation of sensor-recorded lying bouts in lactating dairy cows using a 2-sensor approach. J. Dairy Sci. 98:7911-7916. https://doi.org/10.3168/ jds.2015-9554.

Lawrence, K., N. Broerse, L. Hine, J. Yapura, and W. J. Tulley. 2017. Prevalence of failure of passive transfer of maternal antibodies in dairy calves in the Manawatu region of New Zealand. N. Z. Vet. J. 65:1-5. https://doi.org/10.1080/00480169.2016.1224207.

Liboreiro, D. N., K. S. Machado, P. R. Silva, M. M. Maturana, T. K. Nishimura, A. P. Brandao, M. I. Endres, and R. C. Chebel. 2015. Characterization of peripartum rumination and activity of cows diagnosed with metabolic and uterine diseases. J. Dairy Sci. 98:6812-6827. https://doi.org/10.3168/jds.2014-8947.

Lindsay, D. B., and D. W. Pethick. 1983. Adaptation of metabolism to various conditions: Metabolic Disorders. Pages 431-480 in Dynamic Biochemistry of Animal Production. A. Neimann-Sorensen and D. E. Tribe, ed. World Animal Science, Series A, Basic Information. Elsevier, New York, NY.

López Bernal, A. 2003. Mechanisms of labour: Biochemical aspects. BJOG 110:39-45. https://doi.org/10.1046/j.1471-0528.2003.00023 .x.

Macdonald, K., and J. R. Roche. 2011. Condition Scoring Made Easy. 3rd ed. DairyNZ, Hamilton, New Zealand.

Martín-Tereso, J., and H. Martens. 2014. Calcium and magnesium physiology and nutrition in relation to the prevention of milk fever and tetany (dietary management of macrominerals in preventing disease). Vet. Clin. North Am. Food Anim. Pract. 30:643-670. https://doi.org/10.1016/j.cvfa.2014.07.007. 
Martinez, N., C. A. Risco, F. S. Lima, R. S. Bisinotto, L. F. Greco, E. S. Ribeiro, F. Maunsell, K. Galvão, and J. E. Santos. 2012. Evaluation of peripartal calcium status, energetic profile, and neutrophil function in dairy cows at low or high risk of developing uterine disease. J. Dairy Sci. 95:7158-7172. https://doi.org/10.3168/jds $.2012-5812$.

Mattachini, G., E. Riva, C. Bisaglia, J. C. A. M. Pompe, and G. Provolo. 2013. Methodology for quantifying the behavioral activity of dairy cows in freestall barns. J. Anim. Sci. 91:4899-4907. https:// doi.org/10.2527/jas.2012-5554.

McArt, J. A. A., and R. C. Neves. 2020. Association of transient, persistent, or delayed subclinical hypocalcemia with early lactation disease, removal, and milk yield in Holstein cows. J. Dairy Sci. 103:690-701. https://doi.org/10.3168/jds.2019-17191.

Ministry for Primary Industries. 1999. New Zealand Animal Welfare Act. Part 6. Use of animals in research, testing and teaching. Accessed Aug. 20, 2018. http://www.legislation.govt.nz/act/public/ 1999/0142/latest/DLM50499.html?search=sw_096be8ed817c720c $\_$Part+6_25_se\&p=1.

Murray, R. D., J. E. Horsfield, W. D. McCormick, H. J. Williams, and D. Ward. 2008. Historical and current perspectives on the treatment, control and pathogenesis of milk fever in dairy cattle. Vet. Rec. 163:561-565. https://doi.org/10.1136/vr.163.19.561.

National Institute of Water and Atmospheric Research (NIWA). 2018. National Climate Database. Accessed Aug. 16, 2018. https://cliflo niwa.co.nz/.

Neves, R. C., B. M. Leno, K. D. Bach, and J. A. A. McArt. 2018. Epidemiology of subclinical hypocalcemia in early-lactation Holstein dairy cows: The temporal associations of plasma calcium concentration in the first 4 days in milk with disease and milk production. J. Dairy Sci. 101:9321-9331. https://doi.org/10.3168/ jds.2018-14587.

Neves, R. C., B. M. Leno, T. Stokol, T. R. Overton, and J. A. A. McArt. 2017. Risk factors associated with postpartum subclinical hypocalcemia in dairy cows. J. Dairy Sci. 100:3796-3804. https:// doi.org/10.3168/jds.2016-11970.

Nielsen, S. S., M. A. Krogh, and C. Enevoldsen. 2009. Time to the occurrence of a decline in milk production in cows with various paratuberculosis antibody profiles. J. Dairy Sci. 92:149-155. https: //doi.org/10.3168/jds.2008-1488.

O'Connell, J., P. S. Giller, and W. Meaney. 1989. A comparison of dairy cattle behavioural patterns at pasture and during confinement. Isr. J. Agric. Res. 28:65-72.

Oetzel, G. R. 2004. Monitoring and testing dairy herds for metabolic disease. Vet. Clin. North Am. Food Anim. Pract. 20:651-674. https://doi.org/10.1016/j.cvfa.2004.06.006.

Proudfoot, K. L., and J. M. Huzzey. 2017. Behavior of transition cows and relationship with health. Pages 1055-1065 in Large Dairy Herd Management. 3rd ed. D. K. Beede, ed. Am. Dairy Sci. Assoc., Champaign, IL.

Proudfoot, K. L., J. M. Huzzey, and M. A. G. Von Keyserlingk. 2009. The effect of dystocia on the dry matter intake and behavior of Holstein cows. J. Dairy Sci. 92:4937-4944. https://doi.org/10 $.3168 /$ jds.2009-2135.

Reinhardt, T. A., J. D. Lippolis, B. J. McCluskey, J. P. Goff, and R. L. Horst. 2011. Prevalence of subclinical hypocalcemia in dairy herds. Vet. J. 188:122-124. https://doi.org/10.1016/j.tvjl.2010.03.025.

Ribeiro, E. S., F. S. Lima, L. F. Greco, R. S. Bisinotto, A. P. Monteiro, M. Favoreto, H. Ayres, R. S. Marsola, N. Martinez, W. W. Thatcher, and J. E. Santos. 2013. Prevalence of periparturient diseases and effects on fertility of seasonally calving grazing dairy cows supplemented with concentrates. J. Dairy Sci. 96:5682-5697. https://doi.org/10.3168/jds.2012-6335.

Rice, C. A., N. L. Eberhart, and P. D. Krawczel. 2017. Prepartum lying behavior of Holstein dairy cows housed on pasture through parturition. Animals (Basel) 7:32. https://doi.org/10.3390/ani7040032.
Roberts, K. I., and S. McDougall. 2019. Risk factors for subclinical hypocalcaemia, and associations between subclinical hypocalcaemia and reproductive performance, in pasture-based dairy herds in New Zealand. N. Z. Vet. J. 67:12-19. https://doi.org/10.1080/ 00480169.2018.1527732.

Roche, J. R. 2003. The incidence and control of hypocalcaemia in pasture-based systems. Acta Vet. Scand. Suppl. 97:141-144.

Roche, J. R., and D. P. Berry. 2006. Periparturient climatic, animal and management factors influencing the incidence of milk fever in grazing systems. J. Dairy Sci. 89:2775-2783. https://doi.org/10 .3168/jds.S0022-0302(06)72354-2.

Roche, J. R., P. Dillon, C. R. Stockdale, L. H. Baumgard, and M. J. VanBaale. 2004. Relationships among international body condition scoring systems. J. Dairy Sci. 87:3076-3079. https://doi.org/ 10.3168/jds.S0022-0302(04)73441-4.

Roche, J. R., A. Heiser, M. D. Mitchell, M. A. Crookenden, C. G. Walker, J. K. Kay, M. Vailati Riboni, J. J. Loor, and S. Meier. 2017. Strategies to gain body condition score in pasture-based dairy cows during late lactation and the far-off nonlactating period and their interaction with close-up dry matter intake. J. Dairy Sci. 100:1720-1738. https://doi.org/10.3168/jds.2016-11591.

Roche, J. R., S. Meier, A. Heiser, M. D. Mitchell, C. G. Walker, M. A Crookenden, M. Vailati Riboni, J. J. Loor, and J. K. Kay. 2015. Effects of precalving body condition score and prepartum feeding level on production, reproduction, and health parameters in pasture-based transition dairy cows. J. Dairy Sci. 98:7164-7182. https://doi.org/10.3168/jds.2014-9269.

Sepúlveda-Varas, P., D. M. Weary, and M. A. G. von Keyserlingk. 2014. Lying behavior and postpartum health status in grazing dairy cows. J. Dairy Sci. 97:6334-6343. https://doi.org/10.3168/ jds.2014-8357.

Sheahan, A. J., E. S. Kolver, and J. R. Roche. 2011. Genetic strain and diet effects on grazing behavior, pasture intake, and milk production. J. Dairy Sci. 94:3583-3591. https://doi.org/10.3168/jds .2010-4089.

Silper, B. F., I. Robles, A. M. L. Madureira, T. A. Burnett, M. M. Reis, A. M. de Passillé, J. Rushen, and R. L. A. Cerri. 2015. Automated and visual measurements of estrous behavior and their sources of variation in Holstein heifers. I: Walking activity and behavior frequency. Theriogenology 84:312-320. https://doi.org/ 10.1016/j.theriogenology.2014.12.029.

Susenbeth, A., T. Dickel, K. H. Sudekum, W. Drochner, and H. Steingaß. 2004. Energy requirements of cattle for standing and for ingestion, estimated by a ruminal emptying technique. J. Anim. Sci. 82:129-136. https://doi.org/10.2527/2004.821129x.

Timeanddate.com. 2017. Hamilton, New Zealand-Sunrise, sunset, and daylength. Accessed Feb. 13, 2018. https://www.timeanddate .com/sun/new-zealand/hamilton.

Weary, D. M., J. M. Huzzey, and M. A. G. von Keyserlingk. 2009. Board Invited Review: Using behavior to predict and identify ill health in animals. J. Anim. Sci. 87:770-777. https://doi.org/10 $.2527 /$ jas.2008-1297.

\section{ORCIDS}

S. J. Hendriks @ https://orcid.org/0000-0002-6725-9290 J. M. Huzzey (ํ) https://orcid.org/0000-0003-1644-6608 B. Kuhn-Sherlock @ https://orcid.org/0000-0002-1890-0301 S.-A. Turner (1) https://orcid.org/0000-0003-2654-0673 K. R. Mueller ๑ https://orcid.org/0000-0001-7023-5356 C. V. C. Phyn ( https://orcid.org/0000-0002-4912-4069 D. J. Donaghy @ https://orcid.org/0000-0002-3002-5773 J. R. Roche @ https://orcid.org/0000-0002-4165-9253 